\title{
Reading narratives of privilege and paternalism: the limited utility of human rights law on the journey to reform Northern Irish abortion law
}

\author{
Lynsey Mitchell* \\ Abertay University \\ Correspondence email: 1.mitchell@abertay.ac.uk
}

\begin{abstract}
This article argues that a gendered conceptualisation of rights means that an invisible barrier had to be surmounted when attempting to frame denial of access to abortion in Northern Ireland as a human rights violation. It considers the Supreme Court decisions of In the matter of an application by the Northern Ireland Human Rights Commission for Judicial Review (Northern Ireland) ${ }^{1}$ and $R$ (on the application of $A$ and $B) v$ Secretary of State for Health; ${ }^{2}$ examines what they reveal about the potentiality of human rights law to advance women's rights; and analyses the limited success of human rights litigation in securing reproductive rights for Northern Irish women. It posits that the reason for this is the continued framing of abortion in the United Kingdom as a paternalistic privilege permitted to women only in limited scenarios and locations. It demonstrates how courts implicitly endorse this framing and consequently exclude women's victimhood from the human rights framework.
\end{abstract}

Keywords: abortion; women's rights; European Convention on Human Rights; international human rights law; Northern Ireland; CEDAW; devolution; legal paternalism.

\footnotetext{
* Thanks to the many friends and colleagues who read various versions of this article and to the anonymous reviewers for several helpful suggestions. Thanks to the Northern Irish activists for encouraging fruitful discussion at the New Frontiers in Reproductive Justice Workshop in 2019, from which this article was born.

1 In the matter of an application by the Northern Ireland Human Rights Commission for Judicial Review (Northern Ireland) [2018] UKSC 27 (hereafter NIHRC).

$2 \quad R$ (on the application of $A$ and $B$ ) $v$ Secretary of State for Health [2017] UKSC 41 (hereafter $A$ and $B$ ).
} 


\section{INTRODUCTION}

Despite the achievements of rights-based jurisprudence, scholars have critiqued the inability of law to properly redress gender inequality due to its promulgation of gender and class hierarchies. ${ }^{3}$ This is especially true when it comes to reproductive rights, and there is a vast critique of the (in)ability of law to advance these specifically. ${ }^{4}$ Even when human rights are embedded in cultural and legal consciousness, the prevailing discourse of human rights focuses on public rights that privilege a prioritised legal (male) subject. 5 Thus, reproductive rights are especially contentious and difficult to deliver, even in rights-oriented jurisdictions, because of the supposed threat that women's human rights pose to the hegemonic discourse of liberalism, which still prioritises and elevates the classical formulation of civil and political rights. ${ }^{6}$

This article argues that the courts are unable to situate reproductive rights claims within the traditional liberal understanding of human rights. This is because abortion in the United Kingdom (UK) has

M A Fineman, 'Feminist legal theory' (2005) 13 Journal of Gender, Social Policy and the Law 19; Carol Smart, Regulating Womanhood (Routledge 1992); Karen Knop (ed), Gender and Human Rights (Oxford University Press 2004); M J Frug, 'A postmodern feminist legal manifesto (an unfinished draft)' (1992) 105 Harvard Law Review 1045; Ratna Kapur, Gender Alterity and Human Rights: Freedom in a Fishbowl (Edward Elgar 2018).

4 Joanna N Erdman and Rebecca J Cook, 'Decriminalization of abortion - a human rights imperative' (2020) 62 Best Practice and Research Clinical Obstetrics and Gynecology 11; Sally Sheldon, 'Who is the mother to make the judgment? The constructions of women in English abortion law' 19931 Feminist Legal Studies 3; Eileen V Fegan, 'Subjects of regulation/resistance? Postmodern feminism and agency in abortion-decision-making' 19997 Feminist Legal Studies 241.

$5 \quad$ Ngaire Naffine and other feminist legal scholars have long argued that the law is centred around an idealised legal subject that is male. She argues that this is because law reflects liberalism's distinction between the public and private spheres and assigns to women the role of 'holding the two worlds [public and private] together': Ngaire Naffine, Law and the Sexes: Explorations in Feminist Jurisprudence (Allen \& Unwin 1990) 149. Similarly, Carol Pateman's famous feminist critique of the social contract holds that the social contract theory, as espoused by Hobbes, Locke and Rousseau, not only assumes but is dependent upon women's subordination and relegation to the private sphere. Carol Pateman, The Sexual Contract (Polity Press 1988). Hannah Arendt conceived of citizenship as the 'existence of a right to have rights'. Such conception allows women's rights to be ignored through denying women personhood and the right to their own bodies. See Hannah Arendt, The Origins of Totalitarianism (Meridian 1958) 269. Siobhán Mullally and Claire Murray, 'Regulating abortion: dissensus and the politics of rights' (2016) 25 (6) Social and Legal Studies 645; Kathryn McNeilly, 'From the right to life to the right to livability: radically reapproaching "life" in human rights politics' (2015) 41 Australian Feminist Law Journal 1 
traditionally been understood as a privileged exception from criminalisation and such framing is exceptionally difficult to dislodge. While international and European human rights law has long been promoted as a vehicle for reforming the restrictive abortion regime in Northern Ireland (NI), this rights-based approach has been slow to penetrate the traditional liberal construction of human rights that consequently excludes women's trauma from being understood as a core rights issue. When it comes to litigating harm caused by lack of access to abortion, this article argues that this gendered construction can be seen in the fact that dominant paternalistic narratives around abortion in the UK situate abortion as a privilege and not a right. These narratives are deeply problematic and yet have been implicitly endorsed by the NI and UK courts over the last two decades. This deprioritisation of women's rights-based claims allows the denial of access to abortion to be downplayed as inconsequential and situated outside the mainstream human rights framework. This article examines the two recent Supreme Court decisions on the human rights compatibility of the NI abortion regime and argues that, despite overt demonstrations of sympathy with the appellants' plight, the same implicit gender biases and inherent framing of abortion as a privilege and not a right, which prevented previous legal actions from succeeding, is present in these judgments.

The first section narrates the decades-long fight for reproductive rights in NI and describes how, despite opening new avenues, the adoption of the Human Rights Act 1998 (HRA) did not act as a panacea in redressing lack of access to abortion. It explores how abortion discourse in the UK is rooted in narratives of paternalism rather than women's autonomy, meaning that activists needed to adopt a multijurisdictional and multi-arena approach to making rights claims, rather than simply relying on UK courts to determine that this was a human rights violation.

The next section analyses the decisions of NIHRC and $A$ and $B$ to demonstrate how, despite European Convention on Human Rights (ECHR) jurisprudence and international consensus that lack of abortion in certain circumstances is a human rights violation, in neither case did the appellants convince the court to declare that the NI regime was incompatible with the ECHR. The judgments endorse the aforementioned paternalistic framework of privilege enshrined in the British abortion regime and held the NI regime as human rights compatible because it did not explicitly prevent women from travelling 
to Britain to obtain abortions, in contrast to some jurisdictions. ${ }^{7}$ This, coupled with the fact that the British regime permits access to abortion for Northern Irish women, means that the overall regime was not viewed as a core human rights violation and thus allowed the courts to uphold the status quo, which appears to be that, so long as Northern Irish women were not explicitly prohibited from seeking an abortion in Britain then there was no problem.

Section 4 argues that despite the UK courts' willingness to progressively interpret the ECHR when adjudicating human rights challenges in other contexts, when faced with claims emanating from the restrictive abortion regime in NI, they have been unwilling to situate reproductive rights as core human rights violations. This section highlights how the Supreme Court could have adjudicated the cases in a way that situated the women's experience at the heart of their reasoning. It sets out the lack of discussion in NIHRC and $A$ and $B$ of why the women's pain and suffering was not enough to be conceived as a human rights violation and interrogates the court's reluctance to engage with the progressive international jurisprudence and the gendered reality of unwanted pregnancy.

This article concludes that there is an indeterminacy to women's rights because, even when the tools of domestic and international human rights regimes are being utilised to enforce them, such claims based on reproductive autonomy, dignity, privacy and respect do not invite the full protection of the law because they do not fit the paradigmatic rights violation narrative. It posits that the dominant discourse in the UK has successfully framed abortion as an indeterminate privilege restricted to mainland Britain, rather than an unfettered legal right. Thus, the UK deprioritises women's rights by categorising abortion as a privilege only to be bestowed when the cultural and political hegemony allows, and this framing has proven impervious to human rights challenges because the courts have been unable or unwilling to situate women's experience of abortion prohibition as a core human rights violation. This fits within a wider narrative exposed by feminist and critical legal scholars, whereby women's rights, which generally encompass private rather than public issues, can be deprioritised when they come into conflict with wider public rights. 8

7 The ECtHR has considered cases from Poland where women were explicitly prohibited from obtaining an abortion abroad, whereas it distinguished the prohibition in Ireland because it did not prevent women obtaining abortions abroad. See $A, B$ and $C v$ Ireland App no 25579/05 (ECHR, 16 December 2010); $P \& S v$ Poland App no 57375/08 (ECHR, 30 October 2012); RR $v$ Poland App no 27617/04 (ECHR, 26 May 2011); Tysiac $v$ Poland App no 5410/03 (ECHR, 20 March 2007).

8 Celina Romany, 'Women as aliens: a feminist critique of the public/private distinction in international human rights law' (1993) 6 Harvard Human Rights Journal 87. 


\section{THE HISTORICAL NARRATIVISATION OF ABORTION AS PRIVILEGE}

\section{The UK's two-tier abortion regime and background to reform in NI}

The failure to extend the Abortion Act 1967 (the Act) to NI created a two-tier system of reproductive healthcare in the UK. Women in Britain were free to seek terminations (subject to the provisions of the Act), ${ }^{9}$ yet women in NI could effectively only do so outside NI. ${ }^{10}$ Abortion in NI was until recently governed by the Offences Against the Person Act $1861^{11}$ (OAPA) and section 25 of the Criminal Justice Act (NI) 1945. The OAPA was a criticised archaic framework, with no exception for rape, or saving a woman's life. ${ }^{12}$ Instead in $R v$ Bourne ${ }^{13}$ the English High Court carved out a defence for any doctor performing an abortion 'in good faith' that continuation of the pregnancy 'creates a grave risk that the woman will become a mental or physical wreck'. ${ }^{14}$ Thus, in NI, Bourne remained the definitive interpretation on the circumstances under which a lawful ${ }^{15}$ abortion could be performed until a series of cases in the 1990 s sought clarification. ${ }^{16}$ Even with the clarification,

9 The 1967 Act does not grant rights to women seeking to terminate pregnancy. It instead confers a privilege upon doctors.

10 An amendment to the Northern Ireland (Executive Formation etc) Bill was inserted providing that should there be no functional NI Executive by midnight on 21 October 2019 then s 58 and s 59 of the OAPA would be repealed in NI. See s 9 and s 13(4) Northern Ireland (Executive Formation etc) Act 2019. New regulations came into force in 2020 to provide for access to abortion in NI. See the Abortion (Northern Ireland) Regulations 2020, SI 2020/345 discussed further below.

11 Ss 58 and 59.

12 Sally Sheldon, 'The decriminalisation of abortion: an argument for modernisation' (2016) 36 Oxford Journal of Legal Studies 334, 335; Fiona Bloomer and Eileen Fegan, 'Critiquing recent abortion law and policy in Northern Ireland' (2013) 34 Critical Social Policy 109.

13 [1939] $1 \mathrm{~KB} 687$.

14 Ibid [694].

15 Since the OAPA criminalised 'unlawful' abortion, Bourne confirmed that there were circumstances in which abortion would be lawful. See Sheldon (n 12 above) 341.

16 Northern Health and Social Services Board $v$ F and $G$ [1993] NILR 268; Northern Health and Social Services Board $v$ A and Others [1994] NIJB 1; Western Health and Social Services Board $v$ CMB (Unreported), High Court (Family Division), 29 September 1995; Down Lisburn Health and Social Services Board $v$ CH and LAH (Unreported), High Court (Family Division), 18 October 1995. 
increasingly few legal abortions occurred,17 in part because there was confusion as to when medical professionals might perform one, underscored by a vocal anti-choice climate perpetuated by many in the political establishment. ${ }^{18}$ This uncertainty meant that some women who met the criteria for a legal abortion in NI could not access one. 19 It also meant that most women in NI, even those pregnant as a result of sexual crime or diagnosed with fatal foetal abnormality (FFA) or serious malformation of the foetus (SMF), could not access an abortion in NI, leaving them to either continue the pregnancy or fund travel to Britain to secure an abortion there.

Despite decades of campaigning by reproductive rights organisations in NI, successive UK Governments failed to consider equivalising access to abortion in NI with Britain, ostensibly because NI was considered to be 'different'. ${ }^{20}$ Refusal to extend the Act to NI was continually justified on the basis that legislating for controversial morality issues would be a threat to the fabric of society ${ }^{21}$ and the peace process, ${ }^{22}$ thus foreclosing any discussion of reform. ${ }^{23}$ While British politicians were sensible to be mindful of such claims, the politicisation of abortion and the presentation of it as a 'redline' enabled successive Governments to use the threat of extending the Act to NI as leverage to ensure parliamentary votes and support from NI Members of Parliament (MPs). ${ }^{24}$ This was described as an example of 'women's needs traded

17 Between 2017-2018, 12 abortions were carried out. Department of Health, 'Northern Ireland Termination of Pregnancy Statistics' (Hospital Information Branch 2019).

18 Standing Advisory Committee on Human Rights, Abortion Law in Northern Ireland: The Twilight Zone (SACHR 1993); T McGleenan, 'Bourne again? Abortion law in Northern Ireland after Re K and Re A' (1994) 45 Northern Ireland Legal Quarterly 389.

19 Bloomer and Fegan (n 12 above) 111.

20 Jennifer Thomson, 'Explaining gender equality difference in a devolved system: the case of abortion law in Northern Ireland' (2016) 11 British Politics 371, 379.

21 Catherine O'Rourke, 'Advocating abortion rights in Northern Ireland: local and global tensions' (2016) 25(6) Social and Legal Studies 716, 718.

22 Claire Pierson and Fiona Bloomer, 'Macro and micro-political vernaculizations of rights: human rights and abortion discourses in Northern Ireland' (2017) 19(1) (June) Health and Human Rights Journal 179.

23 Feminist scholarship notes how the common claims as to culture, and the belief that there is cross-community support for maintaining the ban on abortion in NI, were not in fact endorsed by evidence. See L Smyth, 'The cultural politics of sexuality and reproduction in Northern Ireland' (2006) Sociology 40 (4) 663 and O'Rourke (n 21 above).

24 In 2008, there was speculation that the Democratic Unionist Party (DUP) had received assurances from the then Labour Government that if it voted in favour of anti-terror legislation then there would be no attempt by the Government to extend the Act to NI. See Sally Sheldon, 'A missed opportunity to reform an outdated law' (guest editorial) (2009) 4 Clinical Ethics 3, 4; Thomson (n 20 above) 383. 
on the pretext of maintaining the "peace process" in which women have become increasingly marginalised'. 25

This elevation of constitutional settlement serves to perpetuate narratives whereby claims for rights that reflect women's gendered lives are viewed as less compelling than the traditional civil and political rights claims that pertain to male lives. The result is that substantive issues around lack of access to abortion and the suffering this caused were rarely considered, rendering women's rights claims inferior to traditional conceptions of rights that reify male experiences and community cohesion. ${ }^{26}$

Yet, the last two decades have seen a shift in both public and parliamentary attitudes towards reproductive rights. ${ }^{27}$ Much of this was due to the sustained efforts of grass roots activism in NI, 28 which was determined to force the issue either with NI politicians or those in Westminster. ${ }^{29}$ Activists hoped that the passing of the Human

25 Margaret Ward, 'From negotiation of the peace to implementation of the peace agreement: a gender analysis of the Northern Ireland experience' Address at the Roundtable on Gender and Security, 4.

26 There is a growing body of literature that critiques the gendered nature of conflict and post-conflict situations and argues that all too often women's rights and concerns are deprioritised in favour of settlements that support those who were involved in the violence. Some of this literature has traced parallels between the peace agreement and the deprioritisation of women's rights in Northern Ireland. See Fionnuala Ní Aoláin, 'Women, security, and the patriarchy of international transitional justice' (2009) 31(4) Human Rights Quarterly 1055-1085; Catherine O'Rourke, Gender Politics in Transitional Justice (Routledge 2001); Aisling Swaine, Conflict-related Violence against Women (Cambridge University Press 2018); Elish Rooney, 'Women's equality in Northern Ireland's transition: intersectionality in theory and place' (2006) 14(3) Feminist Legal Studies 353375.

27 Sally Sheldon et al, “Too much, too indigestible, too fast”? The decades of struggle for abortion law reform in Northern Ireland' (2020) 83(4) Modern Law Review 761, 774.

28 Alliance for Choice provides direct support to individual women in need of or considering an abortion. It is also a campaigning organisation and works with other advocacy groups, such as Amnesty International, the London Irish Abortion Rights Campaign and the NIHRC and was directly involved in campaigning for a 'Yes' vote in the Republic's referendum on repeal of the 8th Amendment. See Mairead Enright, Kathryn McNeilly and Fiona de Londras, 'Abortion activism, legal change, and taking feminist law work seriously’ (2020) 71(3) Northern Ireland Legal Quarterly 359-385.

29 Enright and others describe how flexibility is a key tool in the arsenal of feminist activists and how pro-reform groups learned to navigate and traverse multiple jurisdictions and forums agitating for change in both the Republic of Ireland and Northern Ireland by means of lobbying, harnessing international human rights mechanisms and the domestic legal system in both Northern Ireland and Britain. See Enright et al (n 28 above). 
Fertilisation and Embryology Act (HFEA) in 2008 would finally extend the Act to NI as this was generally seen as the last chance for reform before criminalisation of abortion was devolved to the NI Assembly.

\section{The path to reform gains momentum: leveraging international human rights law}

Despite disappointment that there was ultimately no amendment to the HFEA to extend the Act to NI, activists continued their campaign and sought instead to utilise international legal mechanisms as well as domestic ones to push for reform. Aware that there was little prospect of securing reform at Stormont, activists worked hard to resituate NI abortion reform as an issue of international human rights compliance, in order to remind the UK Government of its obligation to comply. This strategy allowed them to circumnavigate the hurdle of devolution. In this way 'international human rights law emerged as indispensable to the process for change in NI and a key location for feminist law work'. 30

Activists were optimistic that international human rights law could compel reform because recent years had seen a trend toward interpreting international human rights treaties as providing for access to abortion in situations of sexual crimes and FFA. ${ }^{31}$ Additionally, the Committee on Economic, Social and Cultural Rights (CESCR) calls on states party to the International Convention on Economic Social and Cultural Rights to 'liberalize restrictive abortion laws; to guarantee women and girls access to safe abortion services and quality post-abortion care'. ${ }^{32}$ Regarding the NI regime, in 2016 the CESCR recommended that the UK should 'amend the legislation on termination of pregnancy in Northern Ireland to make it compatible with other fundamental rights, such as women's rights to health, life and dignity'. 33 Various international human rights committees have also called on states to decriminalise abortion and remove punitive sanctions on women. The Committee on the Rights of the Child (CRC) has advocated that abortion

30 Ibid 23.

31 See eg HRC, Amanda Mellet v Ireland (9 June 2016 CCPR/C/116/D/2324/2013); HRC, KL v Peru (22 November 2005 CCPR/C/85/D/1153/2003); CEDAW Committee, LC v Peru (4 November 2011 CEDAW/C/50/D/22/2009); HRC, LMR $v$ Argentina (28 April 2011 CCPR/C/101/D/1608/2007).

32 CESCR, General Comment No 22, The Right to Sexual and Reproductive Health, (2016) UN Doc E/C.12/GC/22 (2016) para 10. See also para 34.

33 CESCR, Concluding Observations on the Sixth Periodic Report of the United Kingdom of Great Britain and Northern Ireland, UN Doc E/C.12/GBR/CO/6 (2016) para 62. 
be decriminalised and called on the UK to 'review its legislation'. ${ }^{34}$ The Committee of the Convention on the Elimination of All Forms of Discrimination Against Women (CEDAW) has repeatedly challenged the NI regime in its UK reports. ${ }^{35}$ In response to criminal prosecutions of women in NI,36 the Human Rights Committee (HRC) in 2015 stated: 'The UK should, as a matter of priority, amend its legislation on abortion in NI.' 37

In the wake of the continuing refusal of both the UK Government and the NI Executive 38 to legislate for appropriate abortion provision in NI, the Family Planning Association Northern Ireland (FPANI), the Northern Ireland Women's European Platform and Alliance for Choice $^{39}$ had requested in 2010 that the CEDAW Committee conduct an inquiry into access to abortion in NI under its Optional Protocol. 40 The submission set out how the regime violated articles

34 CRC, Concluding Observations on the Fifth Periodic Report of the United Kingdom of Great Britain and Northern Ireland, UN Doc CRC/C/GBR/CO/5 (2016) para 65(c).

35 CEDAW, Concluding Observations on the Seventh Periodic Report of the United Kingdom of Great Britain and Northern Ireland, UN Doc CEDAW/C/GBR/CO/7 (2013) para 51, and Concluding Observations on the Sixth Periodic Report of the United Kingdom of Great Britain and Northern Ireland, UN Doc CEDAW/C/UK/ CO/6 (2008) para 289.

36 In 2016, a student who miscarried after taking pills purchased online was found guilty and sentenced to three month's imprisonment (suspended). The facts are narrated in NIHRC (n 1 above) [89]. In 2017, a mother was charged with procuring pills for her 15-year-old daughter. She was only acquitted after the trial judge ordered the jury to acquit her in light of the repeal of the OAPA on 22 October 2019.

37 HRC, Concluding Observations on the United Kingdom, UN Doc CCPR/C/GBR/ CO/7 [Auths/193] (2015).

38 The competency of abortion was transferred to the NI Assembly in the Northern Ireland Act 1998 (Devolution of Policing and Justice Functions) Order 2010.

39 The strategy of appealing to the international human rights regime was spearheaded by Northern Irish reproductive rights activists. See FPANI, Northern Ireland Women's European Platform, Alliance for Choice, Submission of Evidence to the CEDAW Committee Optional Protocol: Inquiry Procedure Research Paper No 15-01 (Transitional Justice Institute 11 February 2015) 6061; Catherine O'Rourke, 'Bridging the enforcement gap - evaluating the Inquiry Procedure of the CEDAW Optional Protocol' (2018) 27 American University Journal of Gender Social Policy and the Law 1.

40 Optional Protocol to the Convention on the Elimination of All Forms of Discrimination Against Women, 1999, United Nations Treaty Series, vol 2131. Reproductive rights organisations in Northern Ireland had realised they could use the Optional Protocol mechanism to force an investigation into the treatment of Northern Irish women due to lack of abortion access. Although this invited the CEDAW Committee to investigate the UK Government's compliance with women's rights, this was a wholly NI initiative organised and instigated by the coalition of NI organisations. 
2, 5, 10, 12, 14 and 16 of CEDAW. ${ }^{41}$ By utilising international human rights mechanisms, these organisations were able to take advantage of these aspirational international human rights documents which positioned abortion as a human right in the aforementioned limited circumstances. This jurisdictional shift was crucial as it allowed the activists to overcome criticism that abortion in NI was a devolved issue and not for the UK Government to remedy. By framing it as a human rights compliance issue, they were able to conceptually shift the responsibility back to the UK Government and, thus, hoped that the 'international scrutiny might embarrass the UK government into taking action'. 42 In 2018, the CEDAW Committee reported its findings, ${ }^{43}$ stating that: 'de facto limitations render access to abortion [in NI] virtually impossible'. ${ }^{44}$ It recommended that the UK 'repeal sections 58 and 59 of the OAPA 1861 so that no criminal charges can be brought against women and girls who undergo abortion or against qualified healthcare professionals and all others who provide and assist in the abortion'. ${ }^{45}$ It further recommended that legislation be adopted to permit abortion on wider grounds and that criminal prosecutions be halted. 46 While the UK Government's response was to continue to hold that abortion was an issue for the NI administration, publication of the report brought further spotlight to the NI abortion regime. It also made clear that the Committee did not consider that devolution absolved the UK Government from its human rights commitments, ${ }^{47}$ which added further momentum to the campaign for reform. ${ }^{48}$

In the midst of this, the UK Supreme Court handed down its two judgments relating to abortion in NI and human rights. While these judgments did not favour the pro-reform lobby, activists were able to capitalise on the publicity around them and so leverage further pressure on the UK Government. Following extensive lobbying by NI activists, in 2019, the House of Commons Women and Equalities Committee published its report on abortion law in Northern Ireland. ${ }^{49}$ The report

41 FPANI et al (n 39 above).

42 O'Rourke (n 21 above) 724.

43 CEDAW Committee, Inquiry Concerning the United Kingdom of Great Britain and Northern Ireland under Article 8 of the Optional Protocol to the Convention on the Elimination of All Forms of Discrimination against Women, Report of the Committee, 6 March 2018, UN Doc CEDAW/C/OP.8/GBR/1.

44 Ibid para 20.

45 Ibid para 85.

46 Ibid.

47 Ibid para 53.

48 For discussion of the multi-pronged approach taken by pro-reform activists in order to leverage international human rights law, see Enright et al (n 28 above) 24.

49 House of Commons Women and Equality Committee, Abortion Law in Northern Ireland (Eighth Report of Session 2017-2019 HC 1584 (2019)). 
made various recommendations, ultimately calling on the Government to produce guidance clarifying the legal position and to legislate for abortion in situations of FFA. 50

These high-profile engagements with NI abortion law all took place against the wider background of the referendum on repeal of the Eighth Amendment in the Republic of Ireland. ${ }^{51}$ This generated huge press coverage throughout the UK and indirectly raised public awareness of the lack of abortion provision in NI.52 Westminster politicians were all too aware that the regime in NI was undefendable. ${ }^{53}$ However, while there was finally a coalition of MPs willing to vote in favour of abortion reform for NI, the Government continued to voice objections to the UK Parliament interfering in an area of transferred competency. ${ }^{54}$ It was proposed (in line with the CEDAW Recommendations as suggested by the pro-reform organisations) that rather than extending the Act to NI, the Government should repeal sections 58 and 59 OAPA, 55 effectively decriminalising abortion 56 in England, Wales and NI. This was seen as an effective compromise between respecting devolution and giving effect to the recommendations of the CEDAW enquiry. Yet, still the UK Government rejected this proposal and maintained that the matter was for the NI Assembly to deal with. 57

50 Ibid ch 10.

51 See Abortion Rights Campaign.

52 Jon Henley, 'Irish abortion referendum: yes wins with $66.4 \%$ - as it happened' The Guardian (26 May 2018).

53 'Joint letter in the Sunday Times to the UK and Irish Governments calling on them to respect women's rights by reforming abortion law in Northern Ireland' The Times (22 July 2018); see also Tom Frost, 'Abortion in Northern Ireland: has the Rubicon been crossed? (2018) 39 Liverpool Law Review 175; Ruth Fletcher, '\#RepealedThe8th: translating travesty, global conversation, and the Irish abortion referendum’ (2018) 26 Feminist Legal Studies 233.

54 Karen Bradley, Secretary of State for Northern Ireland, HC Deb 5 June 2018, vol 642, col 220.

55 Stella Creasy MP convened an emergency debate in the House of Commons making clear that, in the absence of a working assembly in Northern Ireland, such action would not usurp the powers of the NI Assembly: HC Deb 5 June 2018, vol 642, col 208.

56 This was supported by the CEDAW Committee in its inquiry findings and also the Family Planning Association, British Pregnancy Advisory Service (PBAS) and other reproductive rights organisations and is indeed their long-term goal. See 'Campaign groups unite in calling for repeal of sections 58 \& 59 of the Offences Against The Persons Act 1861' Press Release (London Irish Abortion Rights Campaign 5 June 2018).

57 See UK Response to CEDAW, Inquiry Concerning the United Kingdom of Great Britain and Northern Ireland under Article 8 of the Optional Protocol to the Convention on the Elimination of All Forms of Discrimination against Women, Observations of the UK, March 2018, UN Doc CEDAW/C/OP.8/GBR/2, para 5. 
The reality was that the devolved assembly had ceased to function in 2016 and there was no effective governance in NI. Maintaining the position that abortion in NI was an issue for the devolved assembly was increasingly seen as untenable. This political vacuum provided the perfect opportunity for pro-reform activists to leverage further pressure on the UK Government. Not only could they frame abortion as an international human rights issue, but the stalemate meant they could credibly place responsibility for reform with the UK Government, since there was no viable alternative. 58 They were able to successfully argue that the absence of devolved governance obligated the UK Parliament to legislate on the issue. 59

Ultimately, Stella Creasy MP aided by parliamentary researcher Cara Sanquest, a co-founder of the London Irish Abortion Rights Campaign, 60 took up the mantle of legislative reform. After successfully embarrassing the Government into agreeing to fund National Health Service (NHS) abortions for Northern Irish women, ${ }^{61}$ Creasy tabled a series of amendments to technical Bills that dealt with matters arising due to the absence of the devolved assembly. ${ }^{62}$ With the support of a group of cross-party MPs, she eventually pushed through an ambitious amendment that required the UK Government to implement the recommendations of the CEDAW report should the NI Assembly not resume sitting by 21 October 2019.63 In this way, Creasy and other MPs at the behest of NI activists 'successfully and strategically deployed international human rights law in laying the groundwork for the decriminalisation of abortion'.64 Despite last-minute attempts to reconvene the NI Assembly and thus block the repeal, sections 58 and 59 of the OAPA were repealed for NI, decriminalising abortion there. And, finally, in March 2020, regulations providing for abortion in NI came into effect. 65

58 Enright et al (n 28 above) 24.

59 Ibid 25.

60 London Irish Abortion Rights Campaign.

61 Creasy proposed an amendment to the Queen's speech: HC OP 2 (26 June 2017) part 1,5-6. There was speculation that the amendment would pass, embarrassing the Conservative/DUP alliance. Rt Hon Justine Greening MP, Minister for Women and Equalities, Letter to the Members of the House of Commons, 29 June 2017.

62 For full discussion of the work of the London Irish Abortion Rights Campaign and Stella Creasy in achieving legislative reform, see Sheldon et al (n 27 above).

63 S 9 of the Northern Ireland (Executive Formation etc) Act 2019 put an obligation on the Secretary of State to implement the recommendations of the CEDAW Committee by 31 March 2020.

64 Enright et al (n 28 above) 25.

65 The Abortion (Northern Ireland) Regulations 2020, SI 2020/345. The regulations allow for abortion on request in the first 12 weeks of pregnancy. After 12 weeks, abortion is permitted on grounds similar to those in the rest of the UK. See Sheldon et al (n 27 above) 793. 


\section{Reading privilege and paternalism in the NI abortion regime}

The provision of abortion services in NI is a momentous victory for reformers and represents the culmination of decades of NI activism. While such a success is a celebratory moment, it is necessary to examine why such tireless activism was necessary and why the initial turn to human rights law to gain reproductive rights was not more successful in the UK courts. 66

Despite the UK Government's position that abortion was an issue for the devolved NI Assembly, it promotes access to abortion as part of its development programme and considers abortion a key right in advancing gender equality. ${ }^{67}$ It also acknowledges that safe abortion services for victims of rape during war are protected under international humanitarian law. 68 Thus, 'the British Government's endorsement of abortion rights for women in developing countries contrasts greatly with its refusal to intervene to endure such rights for its own citizens living in a devolved region of the UK'.69

Despite such curious cognitive dissonance by the Government, its reluctance to interrogate the NI regime can be understood. The fact that NI had such restrictive abortion provision appears to have allowed the UK Government to narrativise the position in Britain as comparatively liberal.70 Abortion remains a paternalistic ritual in Britain which requires the (male) legal and political establishment to first acquiesce, and then requires individual women to seek

66 While aware that the shift towards human rights framing has been an overall success for the pro-reform lobby and ultimately achieved reform of the law, this article confines itself to an examination of the power of human rights law in the courts. It seeks to question why human rights arguments did not have more traction with the courts. While it also acknowledges that successful feminist activism takes place across a variety of platforms and forums, and that many feminists have low expectations of the power of law to achieve change, for legal scholars it is important to interrogate the power of human rights arguments to advance women's rights and expose entrenched dynamics that inhibit this.

67 Department for International Development, 'DFID's Policy on Safe and Unsafe Abortion' (Department for International Development 2009); Department for International Development, 'Developing a Human Rights-based Approach to Addressing Maternal Mortality' (Department for International Development 2005).

68 UN Security Council, Resolution 2106, UN Doc S/RES/2106 (2013) and UN Security Council, Resolution 2122, UN Doc S/RES2106 (2013).

69 Goretti Horgan and Julia O'Connor, 'Abortion rights in a devolved region of the UK' (2014) 13 Social Policy and Society 39, 40.

70 Rosamund Scott, 'Risks, reasons, and rights: the European Convention on Human Rights and English abortion law' (2015) 24 Medical Law Review 1, 2. 
permission from the medical establishment. ${ }^{71}$ The discourse around abortion conceptualises the regime in Britain as a privilege rather than facilitating universal health rights for women, meaning that women can be discouraged from pressing for further reform, as to do so invites the suggestion that the privilege may be rescinded entirely. ${ }^{2}$ Despite the supposedly liberal nature of British abortion law, the paternalism cemented in the Act and endorsed in positivistic interpretation by the courts 'highlight[s] the potential for the criminal nature of abortion regulation to bear heavily on practice'. ${ }^{73}$ This paternalistic framing underpins much of the conceptualisation of the NI regime, as it prevented the two regimes being viewed in isolation. The reality is that the British and NI regimes have a symbiotic relationship. The existence of the restrictive NI regime allowed the British regime to be narrativised as liberal and feminist, while the existence of the British regime and its availability to Northern Irish women allowed the NI regime to continue without being found to violate human rights, as both the Government and the courts afforded weight to the fact that Northern Irish women could ultimately undergo abortions in Britain thereby absolving themselves of the view that women were forced to continue unwanted pregnancies. This failure to situate the restrictive NI regime as a violation of women's rights is telling. While the twotier system was justified as a sensible legal compromise on a highly politicised issue, such narrativisation only endorses the wider feminist critique that law has proven impervious to calls to reinterpret in a way that includes women's lived experiences.

This narrative of privilege reifies a paternalistic approach to women's bodily autonomy that inhibits activists' attempts to enforce universal rights. Focusing on the formalistic restrictions of the NI regime meant that the British regime was conceptualised as liberal in comparison, belying the truth that abortion in Britain remains highly legalised and

71 Scott cites the list of reasons why the requirement for two doctors was enshrined. One is that it requires the woman to demonstrate a 'seriousness to terminate'. See also Sheldon (n 12 above) 345; Jonathan Brown, 'Scotland and the Abortion Act 1967: historic flaws, contemporary problems’ 2015 Juridical Review 29, 29.

72 That s 1(1)(a) of the Abortion Act 1967 requires women to gain the permission of two doctors even in the first trimester can be read as an obstacle. Scott ( $\mathrm{n} 70$ above). See also Mary Neal, 'Devolving abortion law' (2016) 20 Edinburgh Law Review 399, 399; Stephanie Palmer, 'Abortion and human rights' (2014) European Human Rights Law Review 596, 3. 
regulated by criminal sanctions. ${ }^{74}$ The continued criminalisation of abortion in Britain also leaves the UK far behind the coalescing legal standards advocated by international human rights bodies and suggests that it is inhibiting the UK human rights framework from effectively protecting women and situating denial of abortion as a human rights violation in the way that international human rights commentators may expect it to. Thus, the NI regime served as a helpful scapegoat and detractor from the actuality of the British regime and shielded the Government from any claims that the British regime was in need of reform.

\section{CHALLENGING PRIVILEGE AND PATERNALISM: THE UTILITY OF HUMAN RIGHTS LAW IN SECURING REPRODUCTIVE RIGHTS}

Utilisation of human rights arguments to compel clarification of the NI abortion regime was first tried after the passing of the HRA. Activists had initially hoped this would provide a legalistic lexicon for challenging the lack of abortion provision for Northern Irish women. There was a notable effort to position reproductive rights claims within a distinctly legal vernacular and capitalise on human rights arguments. ${ }^{75}$ Yet, situating the hardship and discrimination of Northern Irish women within such discourse did not produce the sought-after remedies, and law did not provide the much hoped for panacea as the NI courts were reluctant to label these restrictions as human rights violations. ${ }^{76}$

74 The 1967 Act does not decriminalise abortion, and those carried out outwith the terms set out in the Act would be criminal. It provides that: 'a person shall not be guilty of an offence under the law relating to abortion when a pregnancy is terminated by a registered medical practitioner' and meets certain requirements set out in s 1(a)(b)(c)(d). Such abortions would be criminalised in England and Wales under the OAPA and under the common law in Scotland. Although, there is debate over whether Scots law has ever criminalised abortion given that pre1967 jurisprudence allowed for a more liberal regime than in England. See Brown (n 71 above) and Kenneth McK Norrie, 'Abortion in Great Britain: one Act two laws' [1985] Criminal Law Review 475.

75 Enright et al (n 28 above) 9.

76 Ruth Fletcher, 'Abortion needs or abortion rights? Claiming state accountability for women's reproductive welfare' (2005) 13 Feminist Legal Studies 123; Barbara Hewson, 'The law of abortion in Northern Ireland' (2004) (Summer) Public Law 234; Eileen V Fegan and Rachel Rebouche, 'Northern Ireland's abortion law: the morality of silence and the censure of agency' 200311 Feminist Legal Studies 221; Kathryn McNeilly, Claire Pierson and Fiona Bloomer, 'Moving forward from judicial review on abortion in situations of fatal foetal abnormality and sexual crime: the experience of health professionals' (Queen's University Belfast 2016). 
This section revisits this series of challenges and explores why these judgments were conservative at best and openly hostile at worst. It argues that the reason for this was the NI courts' discomfort over adjudicating reproductive rights (which they understood to be contentious and political) and so remained impervious to such claims. It highlights not only the effort needed to achieve small victories for NI reproductive rights in the courts, but how, even where human rights litigation did achieve results, this did not translate to improvements on the ground, and did not force the UK Government or the NI Assembly to act. This demonstrates the liminal nature of human rights and their limited utility in exposing the harm of the abortion regime in NI. Even where challenges were successful, the discourse of human rights did not trump existing narrative framings that drew on morality, culture, religion and NI exceptionalism. 77 This section then traces these themes of paternalism and privilege from these early challenges through to the recent Supreme Court cases. While there has been a shift in judicial discourse towards greater willingness to frame the suffering of Northern Irish women as objectionable and a potential human rights violation, there is still reticence towards affording unequivocal legal remedies. This is rooted in the implicit acceptance that dualistic abortion provision in the UK was permissible so long as Northern Irish women were not explicitly prohibited from travelling to Britain and obtaining abortions there, which ultimately endorses a paternalistic permissive regime; abortion provided to women not as a right but as a privilege only accessible under certain conditions - thus privileging traditional liberal constructions of human rights which serve to exclude women's needs and suffering from the scope of human rights protection.

\section{Early human rights challenges in the NI courts}

In 2003, the FPANI sought a declaration that the NI Minister for Health had acted unlawfully in failing to provide guidance on the availability and provision of services for the termination of pregnancy. ${ }^{78}$ The first instance case was unsuccessful and Bloomer and Fegan note that Kerr $J$ 'showed little understanding of the experience of medics or women when he claimed that this law was clear, although admittedly "difficult to apply"' ${ }^{79}$ Hewson noted that: 'It is arguable that Kerr J's restrictive interpretation of domestic law shows insufficient respect for women's right to physical or moral integrity under Article 8.' 80 While

77 O’Rourke (n 21 above) 717.

78 Family Planning Association of Northern Ireland, Re an Application for Judicial Review [2003] NIQB 48 (hereafter FPANI 2003).

79 Bloomer and Fegan (n 12 above) 112.

80 Hewson (n 76 above) 245. 
the case was an attempt to clarify the law and was thus described as 'morally neutral in substance', 81 it was not perceived this way and was characterised as seeking to change the law 'by the backdoor'. 82 Kerr $\mathrm{J}$ appeared to allow his unease that the FPANI was on record as attempting to liberalise abortion law to influence his rejection of their case. ${ }^{83}$ Fegan and Rebouche noted with concern the court's willingness to allow anti-choice groups access to the litigation on the grounds of morality. ${ }^{84}$ The failure of the court to recognise the very real suffering endured by women, or to situate the lack of guidance as a human rights violation was disappointing, especially as the importance of judicial review to achieving women's equality has been noted by feminist legal scholars. 85

While the FPANI won on appeal 86 and draft guidance was issued in 2009,87 this represented another missed opportunity for the courts to consider the issue of women's autonomy as a human right and to disentangle the patriarchal narratives woven into NI abortion regulation. ${ }^{88}$ In reading in restrictions that did not ostensibly exist, the guidance 'arguably interpreted the existing law more restrictively', 89 thus demonstrating how a judgment in the pro-reformers' favour was also one that further entrenched paternalistic notions over how women should access abortion. Thus, although the turn to the law and invocation of human rights had been useful in compelling the NI administration to act and provide guidance, the guidance itself was so opaque that it did not help facilitate abortion access for women

81 Fegan and Rebouche (n 76 above) 230.

82 Ibid 231.

83 FPANI 2003 (n 78 above) [21]. For commentary, see Sara Ramshaw, 'Commentary on Family Planning Association of Northern Ireland v The Minister for Health, Social Service and Public Safety' in Aoife O'Donoghue, Julie McCandless and Mairead Enright (eds), Northern/Irish Feminist Judgments: Judges' Troubles and the Gendered Politics of Identity (Hart 2017) ch 21, 439.

84 Fegan and Rebouche (n 76 above) 223.

85 Ibid.

86 Family Planning Association of Northern Ireland $v$ Minister for Health, Social Services and Public Safety and others [2004] NICA 37 (hereafter FPANI 2004).

87 Department of Health, Social Services and Public Safety NI, 'Guidance on the termination of pregnancy: the law and clinical practice in Northern Ireland' (2010).

88 FPANI 2004 (n 86 above) [84]. Nicholson LJ's judgment largely ignored the rights of pregnant women, especially when he asserted that it would be wrong to circulate the guidance to pregnant women unless they specifically asked for it. John Kennedy, 'Commentary on Society for the Protection of Unborn Children's Application for judicial review' in O'Donoghue et al (n 83 above) ch 22, 459. Bloomer and Fegan (n 12 above) 112. 
entitled to it because of the chilling undercurrent implicit within it. 90 This meant that, while law had granted a remedy, it was not effective, demonstrating what many feminist scholars have long articulated that law, and even judicial remedy, rarely translates to changing actual women's lives. ${ }^{91}$ As McNeilly notes, it is not enough for judges to state the law but then to abrogate responsibility for its wider application. 92

Kennedy93 describes the paternalism explicit in this case where Nicholson LJ expresses hope that the guidance would encourage those considering an abortion to change their minds, positioning abortion as the ultimate tragedy, and women who seek them as needing to be persuaded otherwise. ${ }^{94}$ It was clear that the judges did not think that the guidance should be encouraging abortion. Thus, the deeply problematic aura of paternalism over abortion and the failure to see women as rational actors rather than pitiful creatures at risk of being exploited by abortion providers is woven into this judgment. The judges did not situate the lack of clarity, which was causing confusion over when to permit abortions and so perpetuating suffering, as a human rights violation. Again, it is suggested that this is because, conceptually, forced pregnancy is not conceived as a core human rights violation. It is further suggested that the judges were aware that women who did not want, or were unable, to continue their pregnancies, could in theory arrange an abortion in Britain, leaving the judges free to provide a decision guided solely by procedural public law principles rather than human rights.

Similarly, when the 2009 guidance was challenged by the Society for the Protection of Unborn Children on the grounds that it was unlawful, ${ }^{95}$ Girvan LJ ruled that it was 'misleading' and ultimately made his own ideological position clear. 96 He disregarded the jurisprudence of the European Court of Human Rights (ECtHR) that provision of information on abortion must be allowed, even in jurisdictions where

90 Horgan questioned whether the purpose of the guidance was to scare doctors from performing abortions. Goretti Horgan, 'Foreword' in A Rossiter, Ireland's Hidden Diaspora: The Abortion Trail and the Making of a London-Irish Underground, 1980-2000 (IASC 2009).

91 The NI activists' frustration with the parameters of law is narrated in Enright et al (n 28 above) 11-14.

92 Kathryn McNeilly, 'Family Planning Association of Northern Ireland v The Minister for Health, Social Service and Public Safety' in O'Donoghue et al (n 83) ch 21, 15.

93 Kennedy (n 88 above) 458.

94 FPANI 2004 (n 86 above) [17].

95 Society for the Protection of Unborn Children, Re Judicial Review [2009] NIQB 92.

96 Bloomer and Fegan (n 12 above) 114. 
abortion was prohibited, 97 and claimed that the guidance was unclear on conscientious objection. ${ }^{98}$ Here again, the denial of reproductive rights to women in NI was interpreted as unproblematic in itself, and, as a result of this case, the guidance was withdrawn in 2010, returning legal uncertainty over when legal abortions could occur. 99

The denial of reproductive rights to women in NI that the continuing legal uncertainty (and apathy of the Department of Health to meet its obligations) caused was adjudicated as unproblematic in itself, and, despite an expectation that such cases be judged solely on legal standards, the subject matter meant that the judge scaffolded morality considerations onto his decision making. ${ }^{100}$ The narrativisation of abortion as a privilege and not a core healthcare right, far less a bodily autonomy or privacy right is implicit throughout this judgment, especially when the judge appears to balance clarifying access to abortion in NI against moral convictions of anti-choice organisations. ${ }^{101}$ Again, this case can be considered morally neutral as it was not about liberalisation, but merely sanctioning the guidance clarifying the existing law to reassure women and healthcare workers and thus facilitate effective access for those legally entitled to an abortion. Yet, the perception was that simply providing the guidance was relaxing the regime and, thus, encouraging abortion. It is clear that the judge was uncomfortable with this and, as such, the hardship that the lack of guidance caused to women became lost in the effort to reify the concerns of religious and anti-choice organisations, again approaching women's rights to access abortion through the lens of privilege and paternalism, rather than as a core right to be upheld by the court.

These early reviews of Government and NI administration policy choices were deliberately limited in their scope and did not seek or envision repeal of the criminal prohibitions on abortion or extending the Act to NI. Instead, they were very carefully targeted actions that sought to clarify the law. The inability of the early cases to convince

97 Society for the Protection of Unborn Children, Re Judicial Review (n 95 above) [37]. See Open Door and Dublin Well Women $v$ Ireland App no 14234/88 (A/246-A), App nos 14235/88 and 14235/88 (1993) 15 EHRR 244, 29 October 1992: the court held that Ireland's ban on counselling services providing information on abortion provisions overseas violated Article 10 ECHR.

98 Society for the Protection of Unborn Children, Re Judicial Review (n 95 above) [45].

99 A final version was issued in 2016 making clear that abortion is only lawful in very limited circumstances: Department of Health, Social Services and Public Safety, Guidance for Health and Social Care Professionals on Termination of Pregnancy in Northern Ireland.

100 Society for the Protection of Unborn Children, Re Judicial Review [2009] NIQB 92 (n 95 above) [3].

101 Ibid [40]. 
the courts to situate these challenges as solely core human rights violations is problematic and demonstrates just how ineffective law is at protecting and advancing the rights of women. ${ }^{102}$

\section{NIHRC: The elusive declaration of incompatibility}

Due to the ever more hostile environment foisted on women in need of an abortion and their medical practitioners in NI and a disturbing trend where a number of women were prosecuted for procuring medication and inducing their own abortions, in 2014 the Northern Ireland Human Rights Commission (NIHRC), having been persuaded by proreform groups to take up the mantle of abortion access in NI, eventually brought judicial review proceedings under sections 4 and 6 of the HRA. ${ }^{103}$ Despite minimal success via human rights vernacularisation previously, the willingness of the UK courts in the intervening years to progressively interpret ECHR jurisprudence, ${ }^{104}$ combined with judgments from the ECtHR that held that denial of access to abortion in certain circumstances was a violation of convention rights, suggested that the NIHRC might finally succeed in forcing the UK Government and NI administration to accept that the NI regime violated human rights and thus compel reform. The NIHRC argued that the effective prohibition on abortion in NI created by sections 58 and 59 of the OAPA and the Criminal Justice (Northern Ireland) Act 1945 violated articles 3, 8 and 14 of the ECHR, as it made no provision for victims of sexual crimes (rape or incest), or in cases where there was a diagnosis of FFA or SMF. 105

In the High Court, Horner $\mathrm{J}$ found in favour of the NIHRC regarding article 8 in situations of sexual crime and FFA106 and issued a

102 Enright and others describe how activists became experts in shifting locations and learned to capitalise on 'failed' cases in other contexts. See Enright et al (n 28 above) 22.

103 In the Matter of an Application for Judicial Review by the Northern Ireland Human Rights Commission in the Matter of the Law on Termination of Pregnancy in Northern Ireland [2015] NIQB 96 (hereafter NIHRC 2015). While the intervention of the Human Rights Commission was welcomed by the pro-reform campaign, some highlighted that previous attempts to convince the Commission to challenge the abortion regime had been ignored. The shift by mainstream rights organisations such as the Commission and Amnesty International to positioning the lack of availability of abortion in NI as a human rights issue was due to the huge effort undertaken by pro-reform activists to situate it as such. See further Enright et al (n 28 above).

104 For an overview of the Supreme Court's progressive and inventive interpretation of human rights law, see Bryce Dickson, Human Rights and the UK Supreme Court (Oxford University Press 2003).

105 NIHRC 2015 (n 103 above) [2].

106 Ibid [173]. 
declaration of incompatibility. ${ }^{107}$ This was heralded as an incredible success and the first time there was overt judicial agreement that the abortion regime in NI violated women's rights. ${ }^{108}$ The decision was momentous because it actually went much further than the Strasbourg jurisprudence, finding substantive rather than procedural breaches of article 8 . However, the decision was appealed by a vocally anti-choice Attorney General.109 The Court of Appeal reversed the declaration of incompatibility on the basis that the devolved assembly had refused to legislate for the issue in 2016 and therefore held that a declaration of incompatibility would challenge Stormont's democratic mandate. ${ }^{110}$ The case was heard by the Supreme Court, which found that the NIHRC did not have standing 111 to bring a case in the abstract. 112

By a majority of four to three (Lord Mance, Lord Reed, Lord LloydJones and Lady Black, with Lady Hale, Lord Kerr and Lord Wilson in the minority), the Supreme Court endorsed a formalistic reading of the Northern Ireland Act 1998 (NIA), rendering the NIHRC powerless to bring such cases, even though this was clearly one of the purposes of its creation. ${ }^{113}$ Despite section 71(2B)(a) of the NIA stating that the 'Commission need not be a victim or potential victim of the unlawful act', the court interpreted this to mean that the NIHRC could only bring its own challenge where there has been 'an unlawful act' and not when it was challenging primary legislation. The majority held that such cases could only be brought by, or on behalf of, an identified victim. 114 Here, the court held that NIHRC was challenging primary legislation, but it had not identified, nor was it acting on behalf of, a potential victim and therefore did not have standing. 115

This restrictive interpretation was disappointing because, as Lady Hale (in her minority opinion on standing) noted, the issue of standing

107 Ibid [5].

108 'Supreme Court finds NI abortion law is in breach of international human rights law' (PBAS 7 June 2018); and 'NI abortion law "breaches human rights"' (BBC News, 30 November 2015).

109 'NI abortion law: Attorney general lodges appeal over high court ruling' (BBC News, 25 January 2016); and 'Attorney General questions Sarah Ewart's right to challenge abortion laws in High Court' Irish News (31 January 2019).

110 Attorney General for Northern Ireland $v$ Northern Ireland Human Rights Commission [2017] NICA 42 [74]-[75] per Morgan LCJ.

111 See Jane M Rooney, 'Standing and the Northern Ireland Human Rights Commission' (2019) 82(3) Modern Law Review 525; and Shona Wilson Stark, 'Northern Ireland's abortion legislation: procedural and substantive confusion over declarations of incompatibility' (2003) 7 Cambridge Law Journal 448.

112 NIHRC (n 1 above). For commentary see Frost (n 53 above).

113 NIHRC (n 1 above) [62].

114 Ibid [56]-[60].

115 Ibid [73]. 
was 'an arid'116 one as there was 'no doubt that the NIHRC could readily have found women who either are or would be victims'.117 Indeed, it did identify several women, but brought the case in its own stead. It did so because:

there is, if not an express, an implied provision that it is the role of the NIHRC to bring this litigation. The NIHRC was best placed to represent the victims because of the resources at its disposal, the expertise it could draw on, its role as a quasi-governmental body that engages with the executive and legislature to ensure that legislation is human rights compliant, its desire for a declaration of incompatibility, and to lessen the burden of the victims. ${ }^{118}$

Thus, in denying the NIHRC standing, the majority denied one of the core purposes of the NIHRC. While this interpretation might be explained through a literal reading of both the NIA and HRA, a purposive reading 'indicates that the NIHRC should have had standing'. ${ }^{119}$ It is telling that a court that has previously been willing to engage in purposive interpretation to radically interpret legislation in accordance with human rights norms decided to revert to judicial conservatism in this instance. Lord Mance appeared to be aware of how controversial and unwelcome his interpretation on standing was as he acknowledged that his conclusion was 'inconvenient', 120 which, as Stark notes, is quite the understatement.121

As Rooney highlights, the result of Lord Mance's opinion is to set the bar exceedingly high for any woman to establish victimhood and be granted admissibility. ${ }^{122}$ Not only does the majority opinion state that the NIHRC lacked standing to bring the case, it appears to suggest that a Northern Irish woman who was denied an abortion on the grounds of either FFA or sexual crime could only challenge the particular grounds that directly affected her. ${ }^{123}$ In his dissenting opinion, Lord Kerr highlights the absurdity that such an interpretation would render, noting that women in such situations 'do not have the luxury of time with which to seek vindication of their rights'. ${ }^{124}$ Indeed, this very issue

116 Ibid [11].

117 Ibid.

118 Rooney (n 111 above) 538.

119 Ibid 525.

120 NIHRC (n 1 above) [70].

121 Stark (n 111 above) 450.

122 Rooney (n 111 above) 541.

123 The High Court appeared to confirm that, as a result of Lord Mance's ruling, a woman who is a victim of FFA could challenge the human rights compatibility of that ground but not the other grounds: In the Matter of an Application by Sarah Jane Ewart for Judicial Review [2018] NIQB 85 at [2].

124 NIHRC (n 1 above) [197]. 
appeared to influence Horner J's first instance conclusion that the law could not intend for only an individual pregnant women to litigate the matter as that would 'be to do a further injustice to them'. 125 Therefore, while cloaked in the vagaries of statutory interpretation, the majority opinion on standing is disappointing and, taken at face value, appears to place further onerous barriers in the path of women challenging the abortion regime.

However, while unable to issue a declaration of incompatibility, the Supreme Court delivered an unusual obiter judgment which effectively stated that, had the case been brought by a named victim, the court would have issued such a declaration. ${ }^{126}$ On the merits, a majority (Lord Mance, Lord Kerr, Lord Wilson and Lady Hale) found that the law in relation to rape, incest and FFA was incompatible with article 8. Lady Black found incompatibility with article 8 only in relation to FFA. Lords Reed and Lloyd-Jones found no incompatibility with either article 8 or article 3, while Lords Kerr and Wilson found incompatibility with both article 8 and article 3.127 This was a highly complex case that caused division between the judges, yet the majority finding that article 8 had been violated merely follows ECtHR jurisprudence, which has held that denial of abortion in cases of FFA can constitute a breach of the ECHR and should not have been especially controversial. ${ }^{128}$ The judges did not feel the need to explore the article 14 claims due to the fact there was a majority finding that article 8 was infringed.

\section{Article 8}

Lady Hale acknowledged that there was 'common ground' that the law interfered with women's article 8 right to respect for privacy. ${ }^{129}$ The question was whether such interference was justified under article $8(2) .{ }^{130}$ In adjudicating whether the article 8 interference was necessary, and whether it struck a fair balance between the rights of

125 NIHRC 2015 (n 103 above) [88]-[89].

126 Following the judgment, Sarah Ewart, who had already provided extensive evidence in the NIHRC case, raised an application as a named victim. In the Matter of an Application by Sarah Jane Ewart for Judicial Review [2019] NIQB 88. The judge referred to the reasoning in NIHRC (n 1 above) and determined that the abortion regime had violated Ms Ewart's human rights.

127 NIHRC (n 1 above) [2].

128 P \& S v Poland; RR $v$ Poland; Tysiac $v$ Poland; $A, B$ and $C v$ Ireland (n 7 above)

129 NIHRC (n 1 above) [19].

130 Article 8(2) states: 'There shall be no interference by a public authority with the exercise of this right except such as is in accordance with the law and is necessary in a democratic society in the interests of national security, public safety or the economic well-being of the country, for the prevention of disorder or crime, for the protection of health or morals, or for the protection of the rights and freedoms of others.' 
the women and the interests of the foetus, the court considered each of the situations. On SMF there was agreement that interference with article 8 rights was not disproportionate and struck a fair balance. ${ }^{131}$ On FFA a majority found that there was no community interest in requiring a woman to carry such a pregnancy to term, with Lord Mance noting that: 'It is difficult to see what can be said to justify inflicting on the woman the appalling prospect of having to carry a fatally doomed foetus to term.'132 On sexual crimes (rape and incest) the court was more divided. The majority found that the interference with article 8 rights could not be justified. The rights of the pregnant woman should take precedence over community interests of protecting the foetus. 133 Again Lord Mance was clear that continuing a pregnancy in such circumstances was undesirable:

The agony of having to carry a child to birth, and to have a potential responsibility for, and lifelong relationship with, the child thereafter, against the mother's will, cannot be justified. ${ }^{134}$

The minority did not think article 8 rights were violated by not allowing for abortion provision in circumstances of sexual crimes. They applied the ECtHR's reasoning in $A B$ and $C v$ Ireland, which found that since Irish women could access abortion abroad then the infringement of their article 8 rights was justified. Here, Lord Reed and Lord LloydJones highlighted that the circumstances were much the same, in that Northern Irish women also had the option to travel to Britain for an abortion. ${ }^{135}$

\section{Article 3}

Only two judges found there to be a violation of article 3. Lord Kerr (the only NI judge) and Lord Wilson found that the law as applied to women in situations of sexual crime and FFA violated article 3 because it is plainly humiliating to require a girl or woman to continue a pregnancy when she knows that the foetus she carries will die or where she finds that pregnancy abhorrent because it is the consequence of rape or incest'. ${ }^{136} \mathrm{He}$ found that the resultant psychological trauma suffered by some women who were denied an abortion in those circumstances would meet the threshold to merit a violation of article 3.137 Lady Hale did not feel it necessary to adjudicate on the article 3 claim since she

131 NIHRC (n 1 above) [133] Lord Mance.

132 Ibid [123].

133 Ibid [27] Lady Hale.

134 Ibid [132] Lord Mance.

135 Ibid [357] Lord Reed

136 Ibid [237] Lord Kerr.

137 Ibid [235] Lord Kerr. 
had found a violation of article 8. The majority (Lord Mance, Lord Reed, Lord Lloyd-Jones and Lady Black) all found there to be no article 3 violation. Lord Mance, also influenced by $A B$ and $C v$ Ireland, noted that Northern Irish women could travel to Britain for an abortion. 138

The judgment can be read as a compromise which created space for Parliament to legislate, while asserting that failure would result in a declaration of incompatibility if a challenge was brought by a named victim. ${ }^{139}$ While the court's caution on a highly contentious issue is understandable, it is problematic as it unquestioningly accepts the political framing of abortion in NI as a contentious morality issue, which is a constructed framing and not a given. The court appears to have been unduly deferential to this constructed political framing.

While many found cause for celebration in the court's strident assessment that the legislative provision was in clear violation of human rights, the lack of judicial remedy highlights the limited power of both women's lived experiences and the utility of pursuing reproductive rights in the UK courts. ${ }^{140}$ This decision represents another example of the tokenistic approach to women's rights. There was much sympathy accorded to individual testimony ${ }^{141}$ and a clear message that such treatment was a violation of human rights. ${ }^{142}$ Yet, ultimately, the court placed a remedy just out of reach by essentially demanding that individual women litigate the same case in their own name. ${ }^{143}$ This was a missed opportunity for the court to deliver a powerful judgment determining that harms suffered by Northern Irish women who could not access abortion were violations of the ECHR. Instead, the court appeared influenced by the fact that Northern Irish women were not prevented from seeking abortions in Britain, reducing the pressing need to determine that the NIHRC had standing and issue a declaration of incompatibility and provide the women with a useful remedy.

Framing abortion as a privilege for 'worthy' cases

This judgment further demonstrates the paternalism at the heart of UK legal reasoning on reproductive rights, which allowed the judges to offer

138 Ibid [100] Lord Mance.

139 Ibid [135]. See Reproductive Health Law and Policy Advisory Group, 'The UK Supreme Court Decision on Human Rights and Abortion in Northern Ireland What Now?'

140 In her feminist judgment, McNeilly notes the failure of the courts in the FPANI cases to situate the applications within human rights law. McNeilly (n 92 above).

141 NIHRC (n 1 above) [85]-[91].

142 Ibid [2].

143 Ibid [61]. 
sympathy to the women whose stories were told in court. ${ }^{144}$ While this showed that the judges were moved by the women's plight, they did not allow this sympathy to influence interpretation of the legislation to enable them to deliver a declaration of incompatibility, nor a majority finding that there was a violation of article 3 . The judgment is carefully crafted to demonstrate empathy and understanding of the hardship and trauma, while making clear that this cannot be redressed by the courts. Instead, the judgment continues law's narrativisation of women as unfortunate victims of circumstance rather than as individual actors seeking redress under the law. It would appear that such women are to be pitied, but not afforded rights or remedy.

The NIHRC was well aware that there is a lack of consensus that there is a general right to abortion. ${ }^{145}$ As such, it deliberately narrowed the scope of the litigation to encompass only the most extreme cases of abortion prohibition (rape, incest, FFA and SMF) in order to take advantage of ECHR jurisprudence and general comments and country recommendations of international human rights committees, thus firmly positioning its argument within demonstrable legal precedent. While this was a strategic position designed to ensure that denial of abortion in the most serious situations be redressed, such a strategy inevitably constructs categories of worthy and unworthy claimants which, inadvertently positions abortion as a 'privilege' awarded only to those women deemed to be most tragic or most deserving, thus continuing the theme of paternalism. Distinguishing categories of women who need an abortion on the basis of harrowing circumstances positions such women as unfortunate creatures, thereby allowing their plight to serve as an exemption to the overall prohibition. While the court's endorsement of a right to abortion on grounds of rape or FFA via a declaration of incompatibility would have been a huge improvement for women in those circumstances, it would do little to shift the dominant narrative framing of abortion as unfortunate and tragic. Instead, it would merely position certain women as so unfortunate that an abortion must be permitted, thereby privileging the most 'worthy' of tragic circumstances. This framing goes to the heart of the court's reasoning. Only where women can be constructed as tragic and pitiable might those women's interests prevail over community interests. In

144 Brid Ní Ghráinne and Aisling McMahon, 'Abortion in Northern Ireland and the European Convention on Human Rights: reflections from the UK Supreme Court' 2019 International and Comparative Law Quarterly 490.

145 There is a general acceptance that international human rights law recognises prohibition of abortion in cases of FFA and rape as a violation of human rights, but there is no consensus on a general right to abortion. It was thus expedient of the NIHRC to litigate only those examples of women denied an abortion in situations of rape, incest, FFA and SFM. 
regimes which permit abortion for these reasons, women need to make sure they fit the characterisation of victimised and desperate in order to invoke law's paternalistic permission. Lord Mance noted that in situations of sexual crime the law should 'protect the abused woman', ${ }^{146}$ which is reminiscent of the language of Bourne where the judge conceptualised women as being 'wrecks'. It was disappointing that such a morally neutral and conservative claim that endorsed law's inherent paternalism toward women did not find more traction with the judges. While this was a sensible strategy designed to mount the best case, it allows the court to solidify problematic abortion narratives that position abortion as tragic but necessary for particular worthy groups of women who can be portrayed as unfortunate victims and demonstrates just how conservative activists have had to be in positioning abortion as a human right.

While the case demonstrates the utility and, indeed, the partial success of pro-choice advocates in situating abortion rights within article 8 jurisprudence, drawing on the successful framing of abortion as both an access to healthcare issue but also as a bodily autonomy issue, it shows how low expectations needed to be and just how conservative the NIHRC's arguments were. Overt claims for reproductive rights premised solely on bodily autonomy arguments that engage article 8 were unlikely to have been endorsed by the courts. This forces activists and lawyers to package arguments for reproductive rights around tragic narratives that rely on women reliving trauma. This further demonstrates the paternalism of law in failing to take women's bodily autonomy seriously and again privileges the traditional liberal understanding of human rights jurisprudence, which excludes women.

Fegan and Rebouche argue that, while healthcare access is a more neutral framing than rights claims based on women's autonomy, a move toward the more overt human rights language of bodily autonomy, privacy, discrimination 147 and inhuman treatment is necessary to fully utilise human rights jurisprudence. ${ }^{148}$ It is clear from NIHRC that the NIHRC attempted to take up this challenge. Its strategy mirroring the global approach that initially framed abortion rights primarily within the sphere of access to healthcare, then incrementally emphasising bodily autonomy as a core human right within the scope of right to freedom from interference in private life.

146 NIHRC (n 1 above) [127] Lord Mance.

147 In Mellet $v$ Ireland (n 31 above) and Whelan $v$ Ireland, Communication No 2425/2014, the HRC adopted a sex discrimination approach that involved contrasting the treatment of the claimants, not with a man in a similar position, but with other women. See Joanna N Erdman, 'The gender injustice of abortion laws' 201927 Sexual and Reproductive Health Matters 1.

148 Fegan and Rebouche (n 76 above) 233. 
This judgment endorses the conceptualisation of abortion as a privilege that not all women are automatically entitled to, by situating it outside traditional liberal understandings of human rights violations. It may be that the judges were reassured that women could still obtain abortions in Britain and so did not conceptualise the suffering and trauma as seriously as they might had the suffering better aligned with traditional jurisprudential understandings of rights violations that violate bodily autonomy, the right to private life or the right to life itself.

Thus, while the NIHRC's approach can be positioned at the forefront of global reproductive rights advocacy, it is disappointing that such an approach packaged within the 'normatively neutral' narrative of access to healthcare ${ }^{149}$ did not appear to insulate the litigation from moralistic overtures and the resultant judicial handwringing; especially since international human rights bodies are moving toward highlighting that in some cases abortion denial can constitute torture or cruel, inhuman or degrading treatment. 150

\section{$A$ and $B$ : the invisibility of gendered arguments on abortion funding and access}

In $A$ and $B$, where the appellants ${ }^{151}$ challenged the now redundant policy 152 of not funding NHS abortions for Northern Irish women who travelled to Britain, the question was whether the Health Secretary's decision not to fund A's abortion was unlawful as a matter of public law and a breach of the ECHR. By a majority of three to two (Lord Wilson, Lord Reed and Lord Hughes, with Lady Hale and Lord Kerr dissenting) the court did not find in favour of the appellants, holding that the Health Secretary was justified in his decision not to fund abortion and that, while there was a violation of A and B's convention rights, such violation could be justified.

The public law arguments advanced were that the Health Secretary had erred in his decision not to provide funded abortions to Northern

149 Daniel Fenwick, “Abortion jurisprudence” at Strasbourg: deferential, avoidant and neutral?’ (2014) 34 Legal Studies 214, 215.

150 Isabella Moore, 'Indignity in unwanted pregnancy: denial of abortion as cruel, inhuman and degrading treatment' (2019) 23 International Journal of Human Rights 1010, 1010; Ronli Sifris, Reproductive Freedom, Torture and International Human Rights: Challenging the Masculinisation of Torture (Routledge 2013).

151 The appellants lodged an application with the European Court of Human Rights. However, the court refused to hear the case on the grounds that a 'friendly settlement' had been reached: $A$ and $B v$ UK No 80046/17 (ECHR 20 December 2019.

152 On 29 June 2017, the UK Government announced that NHS coverage would extend to Northern Irish women accessing abortion in England. See Greening (n 61 above). 
Irish women and hinged on the statutory interpretation of whom was owed a duty. The majority held that the Health Secretary had not failed in his duty by choosing not to extend abortion funding to Northern Irish women on the basis that section 1(1) of the National Health Service Act 2006 stated that this duty extended to the 'people of England'.153 Taking a formalistic approach to interpretation, the majority concluded that Northern Irish women seeking abortions in England could not be considered 'people of England' because NHS regulations specifically prevented people from one devolved nation temporarily registering with a GP elsewhere to avail themselves of better treatment. ${ }^{154}$ The majority were persuaded that: 'Parliament's scheme is that separate authorities in each of the four countries united within the kingdom should provide free health services to those usually resident there.' 155 Thus, Northern Irish women were excluded from any duty that compelled the Health Secretary to fund abortions for people in England, even if they happened to be in England to receive an abortion.

The human rights arguments advanced that abortion services came within the ambit of article 8 and so engaged article 14 (antidiscrimination) as to how those services were provided. The appellants accepted that there was no explicit convention right to an abortion, nor for abortions to be provided free of charge, but argued that where a state did provide abortion services, it must do so in a non-discriminatory fashion. Both the court and the Health Secretary agreed that abortion provision engaged article 8 and thus article 14. The question for the court was, therefore, whether the appellants were discriminated against on the basis of their residency, and, if there was discrimination, whether it could be justified.

\section{Article 14}

Article 14 provides that convention rights shall be secured without discrimination 'on any ground such as sex, race, colour, language, religion, political or other opinions, national or social origin, association with a national minority, property, birth or other status'. Thus, the appellants had to demonstrate that their place of residence (NI) amounted to 'status' under article 14, and as such they should not be discriminated against on this basis. The appellants' argument was not that the NI legislation prohibiting abortion was discriminatory or treated women differently than the English provision, but that denying NHS-funded abortions in England to women normally resident in NI was discriminatory on the basis that such women were afforded

$153 A$ and $B$ (n 2 above) [9]-[16].

154 Ibid [15].

155 Ibid [20]. 
different treatment solely based on their residency in NI. ${ }^{156}$ In Carson, the ECtHR found that place of residence did constitute an aspect of personal status under article 14.157 The court therefore was satisfied that a law which treats residents of a place differently to non-residents differentiates on the basis of personal status within the meaning of article 14.158

Having satisfied the court that the law preventing Northern Irish women from accessing NHS-funded abortions in England was discriminatory, and thus interfered with the appellants' Article 8 rights, they then had to establish that such discrimination could not be justified. It was on this point that the judges disagreed. The majority found that the discrimination was justified and as such there was no violation of the appellants' Convention rights. Their reasoning was that the Health Secretary was correct to uphold the scheme for separate health provision in the devolved regions of the UK. ${ }^{159}$ Consequently, it was lawful to prevent people from one nation contracting better healthcare services in another and to impose a duty on the Health Secretary to fund abortions for Northern Irish women would 'precipitate both a substantial level of health tourism into England from within the UK and from abroad and a near collapse of the edifice of devolved health services'. ${ }^{160}$

Despite taking as its starting point the importance of the devolved nature of health provision throughout the UK, and the need to afford a high degree of respect to the sanctity of devolution, the majority judgment was not explicit on the reason for this, nor why in this instance devolution should trump the protection of individual rights. ${ }^{161}$ Here again, paternalism and privilege are at play, where notions of constitutional rights and maintaining the devolution settlements are privileged over women's right to healthcare and bodily autonomy. While the judgment is not explicit that permitting abortion would be a threat to the peace process, there is an implicit suggestion. ${ }^{162}$ The reference to 'respect' for the sanctity of devolution is not fully explained, yet it conjures similar images to politicians speaking of the need to deny women's rights in order to further constitutional settlements. In suggesting this, the court implicitly reifies the gendered hierarchy at play in law whereby women's human rights are deemed lesser than

156 Ibid [91].

157 Carson $v$ UK 51 EHRR 13 [70].

$158 A$ and $B$ (n 2 above) [47].

159 Ibid [35].

160 Ibid [36].

161 Leanne Cochrane, 'Devolution and discrimination between citizens under article 14 ECHR: preserving local provision’ (2017) 76 Cambridge Law Journal 472, 474.

$162 A$ and $B$ (n 2 above) [20]. 
traditional constitutional rights, which are coded as male and more worthy of protecting. ${ }^{163}$ There is no explanation as to how the court assessed these competing issues and thus decided that the Health Secretary was correct to weigh the balance in favour of respecting devolution. Indeed, so entrenched is this gendered hierarchy of rights that the court saw no inherent problem in its privileging of devolution over the women's human rights, hence its failure to fully explain its rationale.

The fact that the court termed the authority of international human rights bodies as 'slight' meant that it determined that progressive jurisprudence that held that de facto obstruction of access to abortion was a human rights violation did not have sufficient weight to counter the Health Secretary's legitimate aim in restricting abortion funding. ${ }^{164}$ It is disappointing that there was no consideration of the international jurisprudence and curious that the majority was so eager to dismiss such authority. While it is correct that treaties such as the CEDAW, the Convention Against Torture and the International Covenant on Civil and Political Rights (ICCPR) are not directly incorporated into UK law, the interpretation of such treaties by other courts and the United Nations (UN) committees offered convincing evidence of the international trend in situating obstructions in abortion access as a human rights violation. While the majority of the court acknowledged such a trend, they stated that it merely added 'background colour'.165

It is disappointing that the Supreme Court did not frame the legal question to situate the appellant's claim within the wider discourse on access to abortion. Instead, it followed the depressing stance of the Strasbourg court, described as 'deferential, avoidant, and neutral', 166 in focusing on procedural issues only and placed the maintenance of the devolved Assembly's right to make its own healthcare provisions above the rights of women seeking healthcare. The judges appear to have been swayed by the Health Secretary's declaration that the motivation behind this policy was not financial or regional fairness, but to demonstrate respect to the NI Assembly's decision to continue to criminalise abortion in NI by refusing to fund such services for those women should they come to England. ${ }^{167}$ It was not made clear why the

163 See Mullally and Murray (n 6 above) who highlight that the human rights framework is not capable of protecting women's reproductive autonomy. See also Vanesa Sauls Avolio, 'Rewriting reproductive rights: applying feminist methodology to the European Court of Human Rights' Abortion Jurisprudence' (2017) 6(2) Feminists@law.

$164 A$ and $B$ (n 2 above) [35].

165 Ibid.

166 Fenwick (n 149 above).

167 A and $B$ (n 2 above) [20]. 
court considered this to be the case, although the reasoning appears to suggest that so long as Northern Irish women are not prohibited from leaving NI to secure an abortion there is no violation of their human rights, even if refusing them funded treatment puts a huge obstacle in the way of accessing such abortions in Britain. ${ }^{168}$ This again serves as another instance of law being unable to conceptualise the actual lived realities of women, since denying funding was in effect denying access to abortion.

\section{Lack of gender awareness}

Both Lord Kerr and Lady Hale offered strong dissenting judgments that the discrimination could not be justified. While Lord Kerr concurred that the democratic decisions of the NI Assembly must be respected, he questioned why funding abortions for Northern Irish women in England was necessarily understood to be disrespectful. ${ }^{169}$ His Lordship noted that, despite NHS funding in England being for the benefit of the people of England', should a woman from NI visit England and require an appendectomy, such treatment would be funded by the NHS. 170 Lord Kerr suggested that there was a presumption that the appendectomy would be an emergency procedure, whilst an abortion is elective. ${ }^{171}$ He correctly noted that the conceptualisation of an abortion as an elective procedure, especially when there is no option to have an abortion in NI, is a false one. ${ }^{172}$ Yet, the majority did not appear to agree with or endorse this reasoning, stating that it is 'easy to think of other people suffering a grave medical condition who could mount an equally convincing special case'.173 While the majority demonstrated sympathy with A's position, it is difficult not to read their judgment as endorsing the view that accessing abortion services in England was no different to someone from NI attempting to gain better treatment in England than that offered by their local NHS trust. This is buttressed by the fact that there is very little consideration in the majority judgment that, in not affording abortion funding to Northern Irish women who come to England, the policy effectively means that many women would be unable to access an abortion at all. This approach belies the fact that, since there is virtually no abortion provision in NI, any Northern Irish woman who wanted an abortion would by necessity have to travel to England. As Lord Kerr notes: 'This is not an instance of her seeking

168 This framing suggests that the state has only negative obligations to comply with in ensuring women are not denied access to abortion.

$169 A$ and $B$ (n 2 above) [76]-[77].

170 Ibid [52].

171 Ibid [51].

172 Ibid.

173 Ibid [36]. 
what she regarded as a better level of service in England. It was a case of her being obliged to come to the only medical service of which she could avail.'174

As Lady Hale (the only female judge) correctly asserts in her dissenting judgment: 'The NHS there could not provide abortion on a wider basis there even if it wanted to do so.' 175 The failure of the majority to consider that abortion was an entirely different case to any other healthcare concern is problematic and highly gendered. The majority did not appear to consider the fact that abortion was a 'special case' in that it was a healthcare provision only utilised by pregnant women. ${ }^{176}$ Yet, accepting that pregnancy was a special criteria might have negated Lord Wilson's fear that allowing persons from NI to access free NHS services in England would bring about 'the near collapse of the edifice of devolved health services'.177 It is suggested that, not only should the court have distinguished abortion provision from routine healthcare provision, it should have afforded weight to the fact that decisions on abortion funding were inherently gendered due to the fact that denial of access to NHS abortions in many cases means denial of access to any abortion, consequently forcing a woman to either carry an unwanted pregnancy to term or obtain abortion pills illegally in NI. This gendered consequence was highlighted in the Mellet communication, which characterised prohibitive restrictions on abortion as 'a disproportionate, abnormal and unjust existential burden on women, by virtue of being women'.178

Lady Hale correctly begins from the perspective that this case cannot be approached as though it were any other healthcare funding decision or that respecting the funding decisions of other devolved regions was an aim that could be balanced against women's human rights to bodily autonomy. It is disappointing that this gendered reality was not given more attention by the majority and the dispute framed within the human rights jurisprudence on access to abortion rather than seeking funded treatment in a different devolved nation. Much

174 Ibid [70]

175 Ibid [97].

176 Ibid [96].

177 Ibid [36].

178 Whelan $v$ Ireland (n 147 above) Annex I: Individual opinion of Committee Member Yadh Ben Achour (concurring) para 5. 
like the ECtHR's well-criticised judgment $A, B$ and $C v$ Ireland, 179 the majority appeared satisfied that since there was no legal prohibition on Northern Irish women leaving NI to obtain abortions elsewhere then there was no violation. This is a misreading of the fact that no funding means that the state is effectively prohibiting women from obtaining abortions elsewhere and is out of step with international jurisprudence. ${ }^{180}$ It serves to perpetuate reification of the abortion regime in Britain as a privilege not a right, but paradoxically something that Northern Irish women can easily avail themselves of should they wish. This saves the court from needing to criticise the NI regime as it can satisfy itself that the appellants were able to obtain abortions in Britain. However, this framing is incorrect, it endorses the implicit paternalism around abortion in the UK by reifying the obstructive regulation as acceptable and approaches the issue as whether Northern Irish women are prevented from obtaining abortions elsewhere, rather than addressing the fact that the need to obtain one outwith NI is what causes the violation of human rights or that denying funding is akin to denying them an abortion in Britain. ${ }^{181}$ While the reasoning here mirrors the ECtHR in $A, B$ and $C$, the ECtHR's judgments are 'designed to provide a floor and not a ceiling of protection'. ${ }^{182}$ It is well within the purview of individual states to aim for a higher standard. Thus, while Ireland's argument that women were free to obtain abortions abroad was accepted by the ECtHR as striking a fair balance, such reasoning does not translate well to the Supreme Court given the UK Government's endorsement of abortion generally. It is disappointing that the testimony of individual women who demonstrated why being unable to access abortion provision in their home nation is so traumatising was not actually processed by the courts nor adjudicated as the primary issue.

179 Sheelagh McGuiness, 'A, B and C leads to D (for delegation)' (2011) 19 (Summer) Medical Law Review 476; Katherine Side, 'A B and C versus Ireland' (2011) 13(3) International Feminist Journal of Politics 390; Joanna N Erdman, 'Procedural abortion rights: Ireland and the European Court of Human Rights' (2014) 22(44) (November) Reproductive Health Matters 22; Brynn Weinstein, 'Reproductive choice in the hands of the state: the right to abortion under the European Convention on Human Rights in light of A, B \& C v Ireland' (2012) 27 American University International Law Review 391.

180 In Mellet $v$ Ireland (n 31 above) the HRC stated that the costs incurred from travelling were themselves an arbitrary interference with the author's right to privacy: para 7.8 .

181 Commentators have long criticised the Irish abortion regime for similarly exporting vulnerable women to other jurisdictions, yet this is not the solution because there are categories of women who cannot travel. See Ruth Fletcher, 'Contesting the cruel treatment of abortion seeking women' (2014) 22 Reproductive Health Matters 10, 21.

182 Palmer (n 72 above) 6. 


\section{THE DE-PRIORITISATION OF WOMEN'S RIGHTS AND THE FAILED UTILITY OF HUMAN RIGHTS}

In both NIHRC and $A$ and $B$, the court demonstrated sympathy with women's experiences, but this did not translate to a remedy. The decisions demonstrate the inability of the UK courts to situate the actual hardship and trauma facing Northern Irish women as human rights violations. Instead, these decisions can be read as a continuation of the conceptualisation of abortion as a 'privilege' in both Britain and NI whereby, so long as Northern Irish women are not explicitly prohibited from accessing an abortion in Britain, there was less impetus on the courts to make a finding of discrimination or a violation of human rights. This conceptualisation allowed the regime to continue to perpetrate hardship, suffering and discrimination of women in NI because narrativising abortion as a 'privilege' rather than a right reifies the discourse of NI exceptionalism and the devolution settlement as impenetrable. The result is that the status quo was maintained through allowing fundamental rights claims to be transformed into claims for 'elective' health care, 183 devaluing such claims to the extent that they could not penetrate the dominant narrative and so fail to gain traction. This explains the Government's reluctance to submit the UK's dualistic abortion regimes to international scrutiny, as such conception is at odds with the trend toward recognition of reproductive rights in international jurisprudence and activism that frames abortion squarely as a rights issue about dignity and bodily autonomy.

The inability of the Supreme Court in both $A$ and $B$ and NIHRC to position reproductive rights claims solidly within the human rights framework is disappointing, and it is notable that arguments based on violations of article 3 did not gain more discussion as a finding that a state has violated article 3 carries a strong message. ${ }^{184}$ While the majority in NIHRC agreed obiter that there had been a violation of the convention, they were unconvinced that article 3 could be invoked because they held that not every woman in the circumstances before the court would suffer a violation of article 3 on being denied an abortion. ${ }^{185}$ As Ní Ghráinne and McMahon argue, this is a perplexing and somewhat controversial statement by the court. ${ }^{186}$ Although the judges referred to the extensive evidence of the ongoing mental and physical anguish and trauma suffered by women who had been unable

$183 A$ and $B$ (n 2 above) [36].

184 See Ní Ghráinne and McMahon (n 144 above). However, the fact that there remains a stigma where states are found to violate art 3 may contribute to the perception that there is an exceptionally high threshold to clear in order to gain a finding that there has been a violation of art 3 in any circumstance.

185 NIHRC (n 1 above) [100].

186 Ní Ghráinne and McMahon (n 144 above). 
to obtain abortions in NI, for the majority, article 3 was not engaged as the severity of treatment threshold was not reached.187 Yet, there was no sustained discussion or explanation as to why they considered this to be the case. Instead, the court was at pains to distinguish NIHRC from the HRC's decisions in Mellet $v$ Ireland and Whelan $v$ Ireland on the basis that the ECHR necessitated a minimum level of severity of treatment to engage article 3 while article 7 of the ICCPR did not.

This restricted discussion and dismissal of authority is disappointing and appears a missed opportunity for the court to acknowledge that the article 3 jurisprudence has 'broadened in recent years'188 and for it to refer to 'the ECtHR's well-established position that psychological distress and denial of medical treatment can lead to a violation of article 3' ${ }^{189}$ Thus, despite the tenuous celebrations of the court's obiter findings that the NI regime infringed article 8 in respect of sexual crimes and FFA, the court's cursory reasoning is unhelpful. The judges were keen to acknowledge the suffering and indignity experienced by those women who gave evidence, but, with very little discussion, this was clearly held to not amount to either torture or inhuman or degrading treatment. Lord Mance distinguished the case from $P \& S v$ Poland and concluded that the case could only be decided on the assessment of the actual circumstances of the conduct relied on and not a risk that a state may breach article 3.190 Yet, in their minority judgment, Lords Kerr and Wilson were clear that the minimum level of severity did not mean that every woman who became pregnant as a result of rape, incest, or with FFA needed to suffer the same in order to engage article $3 .{ }^{191} \mathrm{It}$ appears a tautology to suggest that, despite evidence that the regime perpetrated inhuman and degrading treatment, the court should not find it to be a violation of article 3 because some women may not find such treatment degrading.

Several judges referred to the women's suffering in their findings that there had been a violation of article 8. Lord Mance referred to the substantial 'trauma',192 'anguish'193 and 'stress'194 suffered by the women in determining an article 8 violation. The majority acknowledged and appeared to consider the psychological impacts of denying abortions to women who had been raped, were victims of incest, or where there was a diagnosis of FFA or SMF, but it still did not

$187 N I H R C$ (n 1 above) [103].

188 Ní Ghráinne and McMahon (n 144 above).

189 Ibid.

190 NIHRC (n 1 above) [100]-[103].

191 Ibid [230]-[262].

192 Ibid [126].

193 Ibid [127].

194 Ibid [126]. 
think this enough to engage article 3. ${ }^{195}$ Lady Hale noted that there is a difference in the standard required to determine a violation of article 3 compared with article 8,196 but that itself does not explain why the judgments engage in such a cursory analysis of article 3 when they were clearly willing to endorse that the women had in fact suffered. Such conceptualisation appears to misread progressive interpretations of article 3 which acknowledge that the pain and suffering experienced by women who were denied an abortion having experienced rape or being diagnosed with FFA would meet the severity of treatment threshold and could be considered a violation of article 3.197

Ultimately, it is disappointing that, in both $A$ and $B$ and NIHRC, the court appeared to be influenced by the idea that, so long as women were not prevented from accessing abortion elsewhere, there was a less pressing need to find a violation of their human rights. While the court correctly identified that in $A, B$ and $C v$ Ireland the ECtHR had accorded a margin of appreciation on abortion to individual states, this was done so on the basis that there was no European consensus on the issue. ${ }^{198}$ While Ireland was found to have violated the applicants' article 8 rights in failing to provide access to abortion, this could be balanced against the Irish Government's aim of protecting foetal life 199 alongside the fact that women could travel to obtain an abortion. ${ }^{200}$ As Fenwick notes, 'the stress and hardship suffered by the women was seen as a necessary concomitant of that choice'. ${ }^{201}$ Yet, such reasoning trivialises the mental and physical suffering of individual women, the invasion of their private lives and the hardship that having to travel to England for a private abortion caused. In $N I H R C$, the majority held that there was no breach of article 3 because women could still avail themselves of an abortion in Britain. However, Lady Hale argued (in respect of article 8) that 'relying on the possibility that [she] may be able to summon up the resources, mental and financial, to travel to Great Britain for an abortion if anything makes matters worse rather than better'. ${ }^{202}$ In $A$ and $B$, the majority appeared to occlude the fact that it was because there was no access to abortion in NI that women were forced to access the provision in England, and thus the

195 Ibid [91], [100].

196 Sifris concludes that in most circumstances the denial of abortion would surpass the minimum threshold to engage art 3. Sifris (n 150 above) 260, See also Moore (n 150 above).

197 Sifris (n 150 above); Ní Ghráinne and McMahon (n 144 above).

$198 A, B$ and $C v$ Ireland (n 7 above) [22].

199 Ibid [237].

200 Ibid [241].

201 Fenwick (n 149 above) 221.

202 NIHRC (n 1 above) [27]. 
suffering was very much a consequence of the restrictive regime in NI. The judges acknowledged that the physical reality of having to travel away from friends and family to receive an abortion, as well as the additional burden of having to privately fund this, represented a strain. ${ }^{203}$ Yet, the underpinning issue, the lack of abortion in NI, which precipitated this need, was not linked to the end results, which was denial of access to NHS-funded abortion services and the fact this caused real suffering. As Gerards notes, the finding that there was a margin of appreciation on the issue of abortion does not mean that domestic courts, especially in jurisdictions that do allow for abortion, cannot find that overly restrictive abortion regimes or the treatment they perpetrate violate convention rights. 204 This appears a missed opportunity as the UK Government (unlike Ireland) could not claim any great ideological basis for restricting access to abortion, so the margin of appreciation offers little guidance when adjudicating the NI regime considering the UK's overall position, and therefore the court could have been much more progressive. In NIHRC, it appears to be a case of selective reasoning, where the court was at pains to sympathise with the hardship and suffering facing women in its determining a breach of article 8 and highlighting the stress and humiliation that being unable to access abortion in NI caused, yet it is unclear why none of this reality impressed a need for the majority to consider it in relation to article 3.205

As Zureick notes, this reflects the fact that incidences of torture or cruel or inhuman treatment tend to be conceptualised as 'largely constructed on the basis of a male paradigm ... ignoring the contexts in which women experience comparable pain or suffering'. ${ }^{206}$. This is an example of law's tendency to reflect male experiences and suffering and privilege a particular legal subject.207 Yet, as Edwards demonstrates, by engaging in a subjective reading of individual circumstances, international courts and tribunals have managed to read international

\section{A and $B$ (n 2 above) [7].}

204 J H Gerards, 'The European Court of Human Rights and the national courts: giving shape to the notion of "shared responsibility" in J H Gerards and J W A Fluren (eds), Implementation of the European Convention on Human Rights and of the Judgments of the ECtHR in National Case Law: A Comparative Analysis (Intersentia 2014) 31.

205 Ní Ghráinne and McMahon (n 144 above) 490.

206 Alyson Zureick, '(En)gendering suffering: denial of abortion as a form of cruel, inhuman, or degrading treatment' (2015) 38 Fordham International Law Journal 99.

207 Hilary Charlesworth, Christine Chinkin and Shelly Wright, 'Feminist approaches to international law' (1991) 95 American Journal of International Law 613; Hilary Charlesworth and Christine Chinkin, 'The gender of jus cogens' (1993) 15 Human Rights Quarterly 63. 
prohibitions of torture and inhumane and degrading treatment as applying to a variety of situations that predominately affected women. ${ }^{208}$ It is disappointing that the Supreme Court did not frame the women's evidenced suffering within article 3.209

Thus, a trend of minimisation of women's lived reality can be seen clearly in these judgments. Despite much heralding of the potentiality of human rights litigation to force legal reform, this article argues that, while there has been demonstrable effort by the courts to empathise and sympathise with the victims, there was a failure to situate the women's pain, trauma, stress and humiliation within core human rights discourse, particularly around article 3 and its inability to afford any remedy. While this follows a trend highlighted by feminist scholars that article 3 jurisprudence has been slow to recognise women's trauma as reaching the minimum level of severity and so be accordingly labelled as torture, inhumane or degrading treatment, it is disappointing that the women's objective reality was not given more consideration by the Supreme Court in either NIHRC or $A$ and $B$. Despite the court being much more willing in both cases to acknowledge a potential infringement of the women's article 8 rights, the obiter nature of the finding in NIHRC and the determination that this could be balanced against the Government's aims of restricting healthcare funding in $A$ and $B$ meant that, despite the sympathy and sensitivity accorded to the women, their claims were not endorsed by the courts and as such in neither case were the claimants afforded an effective judicial remedy.

\section{Ignoring international human rights law?}

In addition to utilising ECHR jurisprudence, the appellants in NIHRC and $A$ and $B$ pointed to progressive international human rights law to evidence general acceptance by UN human rights bodies that denial of abortion in situations of sexual crime and FFA is a human rights violation. ${ }^{210}$ It is disappointing that the courts did not engage more with the international treaty provisions or jurisprudence of the

208 Edwards notes how cases of rape, sexual violence, forced sterilisation, genital mutilation and unsafe abortion could fall within the ambit of torture, inhuman, cruel or degrading treatment. Alice Edwards, 'The feminizing of torture under international human rights law' (2006) 19 Leiden Journal of International Law 349.

209 It is acknowledged that, despite some movement, the ECtHR maintains its high threshold for determining violations of art 3 generally, and so the inability to harness art 3 is not limited to lack of abortion provision. See, for example, Lourdes Peroni, 'The protection of women asylum seekers under the European Convention on Human Rights: unearthing the gendered roots of harm' (2018) 18(2) Human Rights Law Review 347.

210 Christina Zampas and Jaime M Gher, 'Abortion as a human right - international and regional standards' (2008) 8 Human Rights Law Review 249, 284. 
UN committees that consistently calls on states to provide access to abortion in the aforementioned situations and evidences a clear shift in situating abortion denial in the such circumstances as a human rights violation, particularly as several international treaty bodies have gone further and called on states to decriminalise and ensure access to safe abortion. 211

States have been encouraged to adopt clear guidelines stating the circumstances in which abortion is legal212 and to provide financial support for women who might otherwise struggle to afford the service. ${ }^{213}$ Where women have procured illegal abortions, they are not to be refused medical care, nor is the medical care to be conditioned upon prosecution. ${ }^{214}$ The Committee Against Torture held that doing so may constitute cruel, inhuman and degrading treatment. ${ }^{215}$ The HRC has also found denial of abortion access to be cruel, inhuman and degrading treatment. ${ }^{216}$ Regional human rights organisations have continued the trend toward encouraging decriminalisation of abortion. Furthermore, the Parliamentary Assembly of the Council of Europe adopted a report calling on member states to decriminalise abortion and guarantee access to safe and legal abortion for women. 217

As Fine et al conclude, 'an important shift is underway as human rights norms progress beyond the recognition of procedural guarantees in connection with abortion to the establishment of access to abortion

211 UN Committee on the Elimination of Discrimination Against Women (CEDAW), CEDAW General Recommendation No 24: Article 12 of the Convention (Women and Health) 1999, A/54/38/Rev1; UN Human Rights Committee (HRC), CCPR General Comment No 28: Article 3 (The Equality of Rights between Men and Women) 29 March 2000, CCPR/C/21/Rev.1/Add.10.

212 CESCR, Concluding Observations on Peru, UN Doc E/C.12/PER/CO/2-4 (2012) para 21; CESCR (n 32 above) para 17; CEDAW Committee, Concluding Observations on Costa Rica, UN Doc CEDAW/C/CRI/CO/5-6 (2011) paras 32-33(c); CEDAW Committee, Concluding Observations on Kuwait, UN Doc CEDAW/C/KWT/CO3-4 (2011) para 43(b).

213 CEDAW Committee, Concluding Observations on Austria, UN Doc CEDAW/C/ AUT/CO/7-8 (2013) paras 38-39.

214 CESCR (n 32 above) para 28. CEDAW Committee, Concluding Observations on Chile, UN Doc CEDAW/C/CHI/CO/4 (2006) para 20.

215 Committee Against Torture, Concluding Observations on Chile, UN Doc CAT/C/ $\mathrm{CR} / 32 / 5$ (2004) para $7(\mathrm{~m})$.

216 Mellet $v$ Ireland (n 31 above) para 7.6 (2016) and Whelan v Ireland (n 147 above) para 7.6. See also, Human Rights Committee, General Comment No 20, para 3, General Comment No 31, para 6, General Comment No 34, para 21; CAT, General Comment No 2, para 6.

217 Council of Europe Parliamentary Assembly, Resolution 1607 on access to safe and legal abortion in Europe, 15th Sitting, 16 April 2008. 
services as a substantive human rights obligation'.218 They argue that, slowly, states are removing prohibitions against abortion, and those states that maintain de facto denial of abortion services have received negative attention from the UN human rights treaty bodies and the international media. 219

In NIHRC, while Lady Hale and Lord Kerr made reference to interpreting the ECHR in light of international treaties 220 in accordance with the well-established rule of international law on treaty interpretation, ${ }^{221}$ Ní Ghráinne and McMahon note that very little reference was made to international law in the case. ${ }^{22}$ Lord Kerr stated that he would not engage with the HRC's views because 'the status of those decisions and their relevance in domestic proceedings ... are far from straightforward subjects'.223 Lord Mance declared that the HRC's views were 'not authorities as to the position under the ECHR'. ${ }^{224}$ Ní Ghráinne and McMahon argue that the court erred and that 'the views of the HRC are persuasive (albeit non-binding) because the HRC has been mandated to provide "authoritative" and "determinative" interpretations of the ICCPR'.225 The Supreme Court should have taken the HRC's views into account, given that it is such an authority and it had previously given an authoritative decision on abortion in situations of FFA. 226

\section{CONCLUSION}

This article has argued that the reason the courts have been so reluctant to situate denial of abortion access as a human rights violation and offer clear remedies is that there is a pervasive aura of paternalism inherent in the UK's abortion regime. For so long, this has underpinned the unequal dualistic regime and allowed the discrimination and suffering of Northern Irish women to be ignored or balanced against the fact that they can ultimately seek an abortion in Britain, thereby

218 Johanna B Fine, Katherine Mayall, and Lilian Sepúlveda, 'The role of international human rights norms in the liberalisation of abortion laws globally' (2017) 19 Health and Human Rights Journal 69, 76.

219 Ibid; Zampas and Gher (n 210 above) 294.

220 NIHRC (n 1 above) [328].

221 Art 31(3)(c), Vienna Convention on the Law of Treaties 1155 UNTS 331 (adopted 23 May 1969, entered into force 27 January 1980).

222 Ní Ghráinne and McMahon (n 144 above).

223 NIHRC (n 1 above) [330].

224 Ibid [102].

225 Ní Ghráinne and McMahon (n 144 above), 492.

226 See Mellet $v$ Ireland (n 31 above) and Whelan $v$ Ireland (n 147) and Ní Ghráinne and McMahon (n 144 above) 493. 
maintaining a compromise. While it is unfortunate that this narrative has been endorsed by the UK Government, it is deeply problematic to see it endorsed by the courts. Much like the earlier abortion challenges, which are resplendent with moralistic overtures, the Supreme Court appears to have started from the position that abortions ought not to be achieved lightly and that women should experience some hardship, 227 which is narrativised as inconvenience in having to travel and fund abortions in Britain, rather than as suffering or inhuman or degrading treatment. 228

Yet, such a negative framing of a rights issue belies an inherent misconception of what reproductive freedom actually entails and allows the UK to frame the situation in NI as acceptable in contrast to cases in Poland (where the ECtHR ruled that the state had violated human rights by effectively preventing women from obtaining abortions) because the NI regime was not explicitly designed to force women to remain pregnant and give birth. ${ }^{229}$ This demonstrates the power of the prevailing narrative framing of abortion in the $\mathrm{UK}$, which is that it is a privilege rather than a right. This framing has allowed the Government to endorse its own image of the UK as a champion of women's rights by 'permitting' Northern Irish women to access abortion in Britain while concurrently upholding the regressive prohibition in NI, reifying moralistic discourse rooted in NI exceptionalism. ${ }^{230}$ The problem is that this framing meant that women's needs and experiences were silenced because the moralistic and paternalistic narratives make it challenging to present abortion as a matter of access to healthcare, far less bodily autonomy. Despite harnessing the human rights framework, it is difficult for human rights activists to dislodge this dominant framing as the 'option' of undergoing an abortion outwith NI is continually presented as evidence that the regime did not violate human rights. Thus, while the international human rights regime has moved toward increasing recognition of reproductive rights and provided a useful nomenclature for activists, it has only had incremental success in the UK and particularly limited traction in swaying the courts.

227 In $A, B$ and $C v$ Ireland, the ECtHR was accused of endorsing an Irish model premised on the basis that women were free to travel to obtain abortions and part and parcel of that was that the hardship should be necessary: $A, B$ and $C v$ Ireland (n 7 above) [240]-[241]. See Fenwick (n 149 above) 221.

228 In $A$ and $B$, the majority referred to the real dangers of 'health tourism': $A$ and $B$ (n 2 above) [36]. It also acknowledged 'respect for the ethical "pro-life" convictions which inform the law'. While it also mentioned the counter position, it is odd that the court felt the need to display such deference to the 'ethical' position that was described as being at the root of the restrictive NI regime: ibid [6].

229 RR $v$ Poland; $P \& S v$ Poland; Tysiac $v$ Poland (n 7 above).

230 Thomson (n 20 above) 380. 
While the judgment in NIHRC put the UK Government on notice that the regime was unsustainable, the fact that further litigation by victims was necessitated demonstrates that the bar set for women's rights claims to gain traction is exceptionally high. It suggests that, while violations of women's rights attract judicial sympathy, the continual framing of them as subordinate to traditional liberal conceptions of rights means that they can be denied if there are any counter-narratives at work. Ultimately, while the decriminalisation of abortion in NI is a moment of celebration for activists, it is problematic that the Supreme Court was so unwilling to condemn the regime on the basis that it was a clear violation of women's rights. Similarly, while the Government reversed its position of not funding NHS abortions for Northern Irish women, leading Cragg to suggest that the appellants in that case had 'lost the battle but won the war', ${ }^{231}$ such funding remains at the discretion of the state and not because the Government has accepted that it has a duty to do so. As Cragg has cautioned, this means that such funding could potentially become (further) politicised and withdrawn. 232 Moreover, the fact that the Supreme Court did not mandate this provision as a human rights requirement is disappointing. While it was hoped that the progression of $A v B$ to Strasbourg may have offered helpful clarification and the position of international authorities might have played a greater role, 233 it is once again problematic that individuals are forced to resort to such lengths to enforce their rights. Thus, while the last five years have seen significant movement in the NI abortion regime, with various victories resulting from these hardfought grassroots campaigns, the fact that human rights litigation has not proven particularly helpful in bringing about these changes suggests a continuing problem in enforcing women's rights as human rights through the courts.

231 Stephen Cragg, 'Abortion, Northern Ireland and the NHS in England: can respect for devolved governments be a justification for discrimination?' (2017) 4(2) Journal of International and Comparative Law 377, 387.

232 Ibid.

233 Ibid. See $A$ and $B v U K$ (n 151 above). 